Please cite this article as:

Susur, E., Hidalgo, A., Chiaroni, D. (2019).

The emergence of regional industrial ecosystem niches: A conceptual framework and a case study

Journal of Cleaner Production, Vol. 208, pp. 1642-1657.

(DOI: https://doi.org/10.1016/j.jclepro.2018.10.163) 


\title{
The emergence of regional industrial ecosystem niches: A conceptual framework and a case study
}

\author{
Ebru Susur ${ }^{\text {a,b }}$, Antonio Hidalgo a ${ }^{\text {, Davide Chiaroni }}{ }^{\text {b }}$ \\ ${ }^{a}$ Department of Industrial Engineering, Business Administration and Statistics, Universidad Politécnica de Madrid, Spain \\ ${ }^{\mathrm{b}}$ Department of Management, Economics and Industrial Engineering, Politecnico di Milano, Italy
}

\begin{abstract}
The objective of this paper is to understand how industrial symbiosis initiatives can contribute to the emergence of regional industrial ecosystems for sustainability transitions of local industrial production systems (LIPS). We offer a conceptual framework that integrates industrial ecology literature and strategic niche management from the sustainability transitions research field. The framework provides a conceptual foundation for analysing the individual industrial symbiosis initiatives and their aggregated contribution to the emergence of regional industrial ecosystems. Analytically, we conceptualise two different heuristic levels - the local industrial symbiosis experiments level and the regional industrial ecosystems niche level - which are interlinked through three analytical niche processes. We illustrate the merits of our conceptualisation through a case study in an empirical setting where we selected a highly industrialised and rarely explored region; namely, the Autonomous Region of Catalonia in Spain. We identify and analyse eight industrial symbiosis initiatives that evolved during 18 years in the region. In the light of our conceptual framework, the results show that interlinked initiatives from the region have been gradually adding up to emerging regional industrial ecosystems. However, the region is still missing a broad regional network with articulated expectations and visions and shared cognitive, formal and normative rules. If emerging regional network provides support and protection for new initiatives, a regional culture change can be realised to achieve sustainability transition of LIPS employing closed industrial production loops. The theoretical contribution of this paper is that we combine two different research streams that have not often learned from each other and we also develop a novel theoretical approach for ex-post evaluation of industrial ecosystem development in regions. Moreover, our conceptual framework can be extended as a prescriptive management tool for planning and implementation of industrial symbiosis initiatives in Catalonia as well as in other regions.
\end{abstract}

\section{Keywords}

Industrial ecology; Industrial symbiosis; Industrial ecosystems; Strategic niche management; Sustainability transitions; Industrial production systems

\section{Highlights}

- Industrial ecology and sustainability transitions fields were integrated.

- A conceptual framework building on the SNM processes was developed.

- Eight industrial symbiosis initiatives from the same region were analysed.

- Interlinked initiatives have gradually contributed to the regional niche level.

- Results suggested continuous support and protection for the new initiatives. 


\section{Introduction}

Industrial production has been considered crucial for the growth of local economies, especially since the Industrial Revolution. In this respect, the development of local industrial production systems (LIPS), which is composed of agglomerated industries in specific locations, has been central to regional development strategies (UNIDO, 2014). In the meantime, sustainability has become a mainstream concern related to industrial development and problems have emerged related to resource scarcity and environmental pollution due to territorially concentrated industrial production activities from LIPS (Shi, et al., 2010; Liu, et al., 2017; Fernández \& Ruiz, 2009; Côté \& Liu, 2016; UNIDO, 2012).

In this vein, the industrial ecology literature argues that the problematic of the industrial production systems is the linear industrial production routines, which are based on the extract-produce-throw away approach to resources (Frosch \& Gallapoulus, 1989). Scholars in the field have developed industrial symbiosis practices for closing industrial production loops in order to have circular industrial production routines (Sterr \& Ott, 2004). Industrial symbiosis aims to benefit from the advantages of industrial agglomerations in LIPS to adopt and develop industrial ecosystems (Ashton, 2008; Lowe \& Evans, 1995). It is analogous to mimicking the principles of natural ecosystems to the industrial processes (McManus \& Gibbs, 2008; Frosch \& Gallapoulus, 1989; Ehrenfeld, 2003) through physical (resources, materials, water, energy, infrastructure and natural habitat) and non-physical (information, knowledge, expertise, management) exchanges across system actors (Chertow, 2000; Lombardi \& Laybourn, 2012). The regional perspective has been central in this literature, which analyses and discusses various cases where LIPS of varying geographical sizes have implemented industrial symbiosis initiatives to trigger the emergence of regional industrial ecosystems (Boons, et al., 2011; Baas \& Boons, 2004; Ashton, 2009).

Over time, industrial ecology has been conceptualised as a systemic innovation model (Machiba, 2010; Gibbs, 2009; OECD, 2009; Adamides \& Mouzakitis, 2009), which can lead to fundamental technological, organisational and institutional changes in industrial production systems (Adamides \& Mouzakitis, 2009) through interactions of a wide variety of actors. Following this, various scholars from the field have argued and agreed that industrial ecology triggers innovation (Mirata \& Emtairah, 2005; Boons, et al., 2017; Taddeo, et al., 2017; Valentine, 2016; Lombardi, et al., 2012). However, an explicit link between industrial ecology and innovation studies has not yet been constructed.

Along similar lines to the systemic innovations needed due to sustainability concerns, the most salient and promising research stream from innovation studies is sustainability transitions (ST). In the ST field, it is claimed that systemic and radical changes have to be realised, given the important risks associated with ongoing sustainability challenges (Schot \& Geels, 2008; Smith \& Raven, 2012; Markard, et al., 2012). Scholars in the field have studied transitions through fundamental sustainable changes in technological, organisational and institutional terms under influence of a broad range of actors (Truffer \& Coenen, 2012; Geels, 2002; Raven, 2007; Farla, et al., 2012).

However, ST scholars have not paid attention to industrial ecology literature and there are only a few studies from industrial ecology literature that have built on the ST frameworks. Those studies have generally adopted some concepts from the transition literature (e.g. Baas \& Huisingh, 2008; Rotmans \& Loorbach, 2009; Verguts, et al., 2016) and some have made a relatively deep operationalisation of industrial production systems and industrial symbiosis initiatives with analytical lenses provided by the ST field (Gibbs, 2009; Adamides \& Mouzakitis, 2009). However, the way in which transitions into 
industrial ecosystems following industrial ecology principles can take place has not been sufficiently addressed (Gibbs, 2009). Apparently, there is a missing link between these two research fields.

Thus, considering the potential contribution of industrial symbiosis initiatives in the emergence of regional industrial ecosystems addressing sustainability problematic of LIPS, and the missing link between industrial ecology and sustainability transitions literature, we derived the following research question:

How can industrial symbiosis initiatives contribute to the emergence of regional industrial ecosystems for sustainability transitions of LIPS?

To answer this question, we present a conceptual foundation for the operationalisation and empirical assessment of that contribution. Accordingly, we first developed a conceptual framework integrating the industrial ecology literature and SNM framework from the ST field. The SNM framework underlines the importance of experimentation and focuses on aggregation of niche experiments for developing niches that would lead to sustainability transitions (Weber, et al., 1999; Schot \& Geels, 2008). So far, SNM framework has not been applied as a policy tool for introducing new sustainable technologies and practices; instead, it has been used as ex-post analytical framework for ex-post analysis and evaluation of cases such as biofuels (Van der Laak, et al., 2007), biomass gasification (Verbong, et al., 2010), organic food (Smith, 2006), biogas plants (Geels \& Raven, 2006), sustainable transport innovations (Weber, et al., 1999) with a particular focus on battery powered vehicles (Kemp, et al., 1998) and hybrid electric vehicles (Sushandoyo \& Magnusson, 2014).

The SNM studies elaborated on three internal processes of SNM that are eminent for understanding the niche development trajectories (Geels \& Raven, 2006; Schot \& Geels, 2008; Van der Laak, et al., 2007): (i) articulation of expectations and visions; (ii) building of social networks; and (iii) learning activities. The framework indicates that these three interacting, mutually reinforcing and co-evolving processes lead to a niche development process, which progresses at two levels concurrently: the local projects level and the global niche level (Schot \& Geels, 2008; Raven, 2005; Raven \& Geels, 2010). The local projects level is composed of individual niche experiments that can build on each other over time (Geels \& Raven, 2006) and the global niche level results from sequences and accumulation of these experiments transcending local contexts (Smith \& Raven, 2012) through three internal niche processes.

In our conceptual framework, we show that the SNM perspective provides useful insights for the reconceptualization and empirical analysis of industrial symbiosis initiatives and regional industrial ecosystems. We argue that local industrial symbiosis initiatives and regional industrial ecosystems can be conceptualised as two heuristic levels and the emergence of regional industrial ecosystems can be explained by first identifying the local initiatives and then analysing their aggregating contribution through three analytical niche processes. Illustrating the merits of our conceptual framework, we employed a case study involving eight industrial symbiosis initiatives distributed over 18 years from the Autonomous Region of Catalonia in Spain (referred to hereafter as Catalonia) to understand the emergence of regional industrial ecosystems.

The main theoretical contribution of this paper is that we integrate two different research streams industrial ecology and the SNM framework from ST field - that have not often learned from each other, and we develop a comprehensive framework that provides the conceptual grounds for an empirical assessment of how contribution of set of industrial symbiosis initiatives to emergence of regional industrial ecosystems can be understood and explained. Operationalisation of our conceptual framework 
in a real setting also enables a novel case study methodology for industrial ecology literature, which did not provide an explicit methodological focus on a wide set of industrial symbiosis initiatives as separate units of analysis from the same region for assessing the emergence dynamics of regional industrial ecosystems. Introducing insights from the sustainability transitions field, we generate new understandings by means of new empirical evidence from the Catalonia region, which has not been studied in the industrial ecology literature before. That regional empirical study illustrated our conceptual approach on how to study cumulative contribution of a set of industrial symbiosis initiatives to the regional industrial ecosystems and resulted in empirical assessments for the chosen region. That may guide other studies to analyse other relevant contexts with a refined or the same conceptual approach as ours.

Moreover, the developed conceptual framework is used in this paper as an analytical lens for ex-post evaluation (e.g. Schot \& Geels, 2008; Raven \& Geels, 2010; Van der Laak, et al., 2007; Verbong, et al., 2010) of industrial ecosystem development in a region, but it can also be extended as a prescriptive management tool for planning and implementation of industrial symbiosis initiatives, both in Catalonia and in other regions. Finally, this paper also has some practical implications as it contributes to better understanding of complex dynamics for the emergence of regional industrial ecosystems, which strongly relates to decisions and actions of industrial actors of all sizes, non-governmental organisations, entrepreneurs, universities and research institutes.

The remainder of the paper is structured as follows. In Section 2, we develop a conceptual framework, integrating industrial ecology literature and the SNM framework. Then, in Section 3 we present our methodology detailing the design of the selected regional case as our empirical context, triangulation in data and insight gathering, and finally data and insight analysis. In Section 4, we provide results and discussions through analysis of eight industrial symbiosis initiatives from the region in light of our conceptual framework. We present our interpretations on how those initiatives have been contributing to the emergence of regional industrial ecosystems for sustainability transitions of LIPS in the selected region. Finally, in Section 5, we offer our conclusions together with our contributions, implications and some suggestions for future research avenues.

\section{Conceptual framework}

In this paper, we approach industrial ecology as a systemic innovation model and emphasise the emergence of regional industrial ecosystems, considering the importance of regional focus in industrial ecology literature (Boons, et al., 2011; Ashton, 2009; Deutz \& Gibbs, 2008; Ristola \& Mirata, 2007), through industrial symbiosis initiatives aiming at the sustainability transitions of LIPS in a region. Integrating industrial ecology literature and the SNM framework, we developed a conceptual framework (Fig. 1) that can be used in real settings for understanding and explaining the contribution of industrial symbiosis initiatives to the emergence of regional industrial ecosystems. Our framework distinguishes two mutually reinforcing and coevolving levels of analysis: the local industrial symbiosis experiments level and the regional industrial ecosystems niche level. 


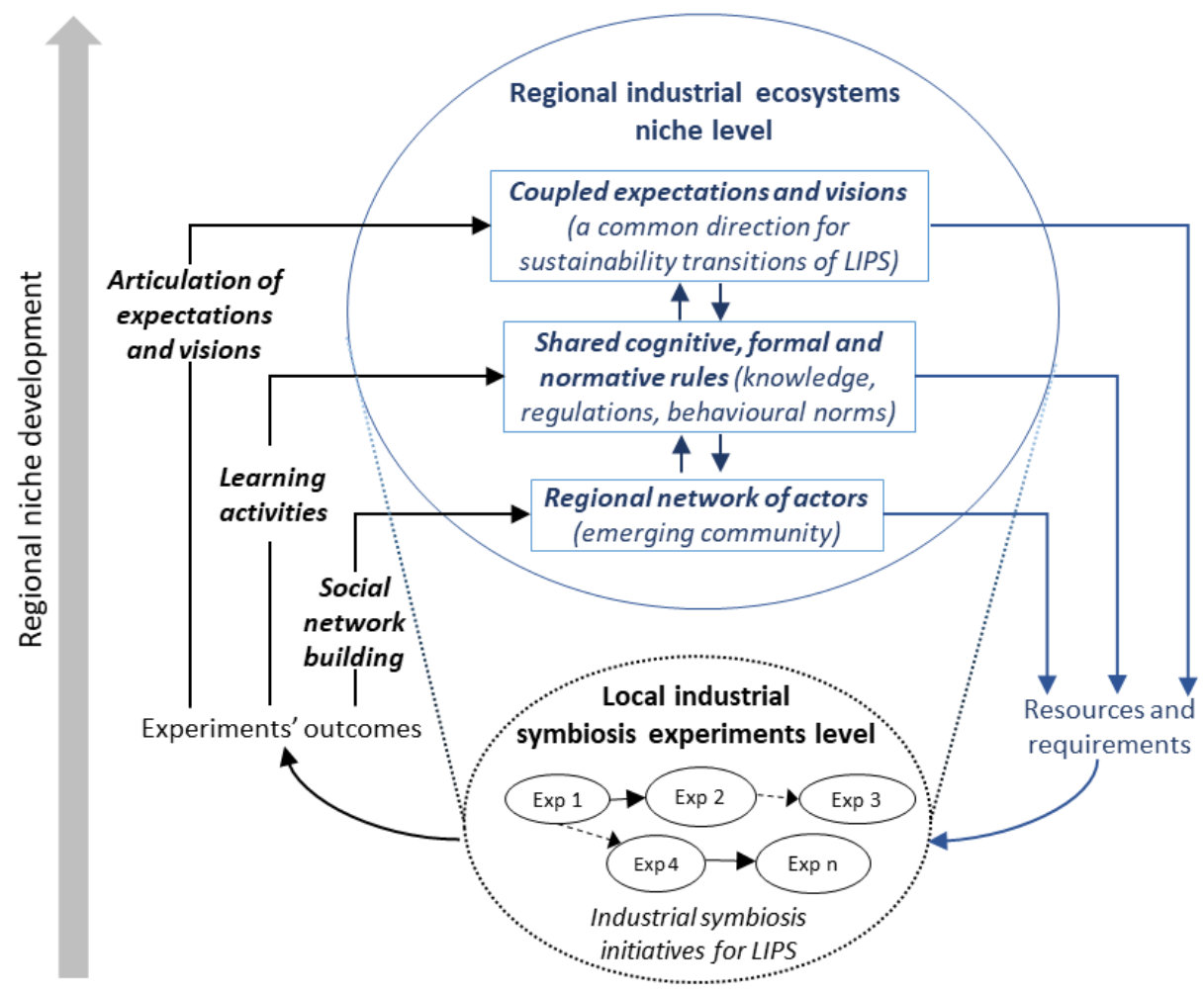

Fig. 1. Conceptual framework. Emergence of regional industrial ecosystems for sustainability transitions of LIPS. Adapted from (Geels \& Raven, 2006; Schot \& Geels, 2008; Baas \& Boons, 2004; Raven \& Geels, 2010).

The first level is the local industrial symbiosis experiments level, which is composed of individual local industrial symbiosis initiatives. At this level, we conceptualise industrial symbiosis initiatives - that are, practical applications of industrial ecology - as local niche experiments. We refer to industrial symbiosis initiatives as any kind of experiment in the form of a project, research, task, mission, network formation action, etc. that may have been completed or on-going with an objective of supporting sustainability transitions of LIPS in the specific geography under focus. The industrial ecology literature provides a rich set of case studies on various industrial symbiosis initiatives, among the most studied of which are Kalundborg (Valentine, 2016), Kwinana (Giurco, et al., 2011), Tianjin (Yu, et al., 2014), Dalian (Geng, et al., 2008), Ulsan (Behera, et al., 2012) and Devens (Veleva, et al., 2015). Our approach has a wider focus than most of those studies, with the intention of involving multiple initiatives from the same region. Such an approach is prominent in the SNM studies but has received scant attention in the industrial ecology literature. More significantly, we stress the need to analyse the interlinkages between multiple initiatives (that is, in forms of either direct support or influence) and the potential aggregation of those initiatives for building regional industrial ecosystems, which is addressed in the next heuristic level of our framework.

The second level is the regional industrial ecosystems niche level following the underpinnings of the SNM framework regarding differentiation between the local projects level and the global niche level (Raven, 2005; Schot \& Geels, 2008; Geels \& Raven, 2006; Raven \& Geels, 2010). We conceptualise regional industrial ecosystems at the niche level as a regional network of actors representing an emerging community that can overcome the lock-in to the linear industrial production routines in the region through establishing shared cognitive and normative rules and coupling expectations and visions of its wide variety of actors. Industrial ecosystems at the regional level have been studied in the industrial ecology 
literature before. The most relevant study to our conceptualisation was conducted by Baas and Boons (2004), who emphasised an evolution of regional industrial ecosystems at different stages of regional efficiency based on firms' autonomous decision-making and regional learning, based on mutual recognition, before arriving at the stage of sustainable districts based on actors' strategic vision on sustainability. Nevertheless, the majority of the industrial ecology literature has approached regional industrial ecosystems as a regional industrial symbiosis network of industrial organisations (Heeres, et al., 2004; Ashton, 2009) and has not explicitly analysed the network building by wide variety of regional actors - that is, formal institutions, research centers and universities, non-governmental organisations, entrepreneurial organisations, etc. - together with industrial organisations. Those actors are potentially engaged in learning activities collectively and, as such, contribute to articulation of expectations and visions in the region, which are actually considered as core elements for the niche building in the SNM studies (Van Eijck \& Romijn, 2008; Coenen, et al., 2010; Van der Laak, et al., 2007; Weber, et al., 1999).

While conceptualising the links between two heuristic levels of our framework, we bring insights from the SNM studies (Geels \& Raven, 2006; Raven \& Geels, 2010) and argue that individual local industrial symbiosis experiments at the first level can build on each other and gradually add up to a regional industrial ecosystems niche level over time. For this gradual process, we specifically distinguish three interacting analytical processes building on the SNM framework: the articulation of expectations and visions, social network building and learning activities, which can be seen as aggregating outcomes of initiatives from the local industrial symbiosis experiments level.

\section{Articulation of expectations and visions}

Articulation of expectations and visions is the first niche process considered for successful niche building in the SNM framework (Schot \& Geels, 2008), which explains that when expectations and visions are specific, tangible, robust and shared by a wide variety of actors (Raven, 2005; Caniëls \& Romijn, 2008; Coenen, et al., 2010), they can be coupled to address certain sustainability challenges through building more effective niches (Weber, et al., 1999).

Concepts of expectations and visions were considered in industrial ecology literature, but not comprehensively and explicitly in central arguments of the studies. Scholars from the industrial ecology field touched on different aspects of actors' expectations from industrial symbiosis initiatives, such as the importance of managing institutions' and community's expectations for sustainability benefits to regions (Deutz \& Gibbs, 2008; Rosano \& Schianetz, 2014); the role of institutional capacity in forming expectations (Boons \& Spekkink, 2012); the problematique of over-inflated and unrealistic expectations of developers and policymakers (Deutz \& Lyons, 2008; McManus \& Gibbs, 2008; Sterr \& Ott, 2004); the significance of diverging expectations (Baas \& Boons, 2007) and converging expectations of actors (Valentine, 2016); and evolving expectations during the construction of industrial symbiosis networks (Ashton \& Bain, 2012).

Furthermore, the vision concept was also addressed in industrial ecology literature in terms of building and expanding the vision of industrial ecology (Ashton \& Bain, 2012; Adamides \& Mouzakitis, 2009; Korhonen, et al., 2001; Gibbs, 2008; Chertow, et al., 2008); emphasising the importance of having a common strategic vision of sustainable development by regional actors (Baas \& Boons, 2004; Spekkink, 2013; Veleva, et al., 2016; Daddi, et al., 2016; Rosano \& Schianetz, 2014) and having a leader, a champion (Hewes \& Lyons, 2008) or an anchor firm (Mulrow, et al., 2017) in the region to tout this vision; and also 
explaining the national level visions of countries like China and South Korea for transforming LIPS into national level industrial ecosystem networks (Yu, et al., 2015).

Yet, only a few studies have addressed the articulation of expectations and visions during the evolution of regional industrial ecosystems (Baas \& Boons, 2004; Baas \& Huisingh, 2008; Boons \& Spekkink, 2012). In this vein, bringing the SNM perspective to our conceptual framework, we further elaborate on the importance of that articulation process in creating coupled expectations and visions that can lead to a common direction for the journey of sustainability transitions of LIPS. Such a challenging long-term journey can be completed if new local industrial symbiosis experiments in the region are continuously designed with visioning in line with coupling expectations and visions of the regional actors and if regional expectations and visions are robust, specific, ambitious and, at the same time, realistic.

\section{Social network building}

The second niche process is about network building (Schot \& Geels, 2008) in the SNM literature, which argues that if the local networks are broad, deep and heterogenous (Van der Laak, et al., 2007) - that is, inclusive to a variety of relevant actors from different experiments involving industrial organisations, formal institutions, non-governmental organisations, research centers and universities, etc. (Coenen, et al., 2010) - then a wider community can emerge with dedicated actors for protecting and supporting the niche building process in terms of facilitating resources and requirements for both new and already-developed local projects (Raven \& Geels, 2010).

Network building has been a central topic in industrial ecology literature as well, while mostly referring to industrial symbiosis exchange networks between industrial organisations. Scholars from the industrial ecology field have looked at different aspects of network building, such as growth patterns of symbiosis networks (Zhu and Ruth 2014); structural characteristics and the role of different actors in symbiosis networks through social network analysis perspective (Chopra \& Khanna, 2014); multiple dimensions of embeddedness in symbiosis networks (Ashton \& Bain, 2012); social relationships between industrial organisations (Ghali, et al., 2014); the role of trust and local champions in industrial symbiosis networks (Hewes \& Lyons, 2008); and the importance of coordinating bodies to facilitate symbiotic connections between industrial organisations (Tessitore, et al., 2015). However, relatively few studies have focused on network building covering a variety of actors, such as governmental organisations, universities and research institutes, non-governmental organisations, and local communities (Baas \& Boons, 2004; Boons, et al., 2011), rather than only focusing on industrial organisations in the symbiosis networks.

Incorporating the SNM approach, our conceptual framework holds such a wider network perspective, covering relevant regional actors (governmental and non-governmental organisations, research centres and universities, local champions, managing/coordinating bodies, entrepreneurs, local community, etc.) that participate in the planning and implementation of industrial symbiosis niche experiments. We propose that local industrial symbiosis experiments can lead to a regional network of actors as an emerging community for regional niche building if social network building process is broad, deep and heterogenous enough to involve multiple stakeholders and to mobilise their available resources. Such an emerging community can protect on-going regional niche building process and bring support in terms of necessary resources and requirements for continuous industrial symbiosis experimentation in the region. 


\section{Learning activities}

The final niche process is related to learning in the SNM framework (Schot \& Geels, 2008). The learning concept has been widely addressed in the industrial ecology literature. Going back to the roots of industrial ecology, its essential argument was based on learning from an analogy with nature and its ecosystems (Frosch \& Gallapoulus, 1989). Then, the industrial ecology literature gave considerable attention to collective learning by the industrial organisations in production systems (MacLachlan, 2013; Grant, et al., 2010) and on collective learning by all relevant regional stakeholders (Baas \& Boons, 2004; Roberts, 2004; Veleva, et al., 2016; Lambert \& Boons, 2002) through means of communication events (trainings, seminars, conferences, workshops, etc.), media (television, radio, internet, newspapers, magazines, etc.), and information communication technologies (information and knowledge sharing and management platforms).

Building on and extending those studies, our conceptual framework emphasises regional collective learning to create a regional shared culture, which we define as shared cognitive, formal and normative rules that refer to common knowledge, required regulations and converging behavioural patterns of the network actors respectively building on the SNM literature (Geels \& Raven, 2006; Geels, 2004; Raven \& Geels, 2010). Learning activities are not only expected to trigger first-order learning through which actors can identify a problem and correct it without changing the underlying rules, but also - and even more importantly - they may facilitate second-order learning through real implementations (Boon, et al., 2014). Consequently, a regional shared culture may be constructed through changes in the underlying rules and status quo governing the mainstream behaviour (Mirata \& Emtairah, 2005; Argyris, 1997; Schot \& Geels, 2008). The second-order learning can be enforced by developing tacit knowledge (Ghali, et al., 2014) by continuous experimentation with local industrial symbiosis projects and exchange of good local and international practices and experiences (Boons, et al., 2017) through effective interactions and dialogues (Baas, 2011). Moreover, second-order learning can be achieved more smoothly if there are regional champions (Hewes \& Lyons, 2008; Qu, et al., 2015) and coordinating bodies (Domenech \& Davies, 2011; Boons \& Spekkink, 2012) that can act as good examples and facilitate interactions, creation of common language, and joint-problem solving for a wide variety of regional actors.

Our conceptual framework proposes that proper combination of these three processes can lead to the emergence of a regional industrial ecosystems niche level that involves a regional network of actors holding coupled expectations and visions through shared cognitive, formal and normative rules. This regional niche level then can provide support and protection measures for the resources and requirements - tax regime, environmental regulations, policy programmes, financing incentives, etc. - needed to plan and implement new industrial symbiosis niche experiments in the region. Thus, we conceptualise a continuous feedback mechanism between two heuristic levels of analysis that may lead to continuity and stability in regional industrial ecosystem development. We propose that if this feedback cycle sustains for long enough, a regional culture change may occur and LIPS in the region may employ closed industrial production loops and experience sustainability transitions into circular industrial production routines.

Similar to the conceptual frameworks of the ST field, such as the multi-level perspective (Geels, 2002; Kemp, et al., 1998) and the technological innovations systems framework (Bergek, et al., 2008; Hekkert $\&$ Negro, 2009), these two levels in our framework are not claimed to provide ontological descriptions of reality, but they are developed as analytical and heuristic concepts (Geels, 2010; Walrave \& Raven, 2016), 
which can guide us to understand and explain the complex dynamics of the emergence of regional industrial ecosystems in real settings.

\section{Methodology}

In this paper, we employed a case study methodology to empirically assess how industrial symbiosis initiatives can contribute to the emergence of regional industrial ecosystems for sustainability transitions of LIPS. Case study methodology is commonly used to answer "how" questions by focusing on understandings of the dynamics and processes in particular settings (Eisenhardt, 1989) and it provides a solid foundation for constructing "context-dependent knowledge" (Flyvbjerg, 2006), while studying complex and contemporary research objects (Yin, 2014) like industrial ecosystems. While designing, analysing and interpreting our case study, we have used our conceptual framework to improve the explanatory power of the study (Dubois \& Gadde, 2002) and to illustrate the merits of our conceptualisation approach when applied to a real setting.

\subsection{Case selection and design}

The empirical setting of the case study was chosen to be Catalonia from Spain, which has not been a focus for related research studies despite its diverse and rich industrial production culture and routines embedded in a long industrial tradition. The region was one the early adopters of British industrialisation model in the nineteenth century. Manufacturing sector has been a main employing sector in the region; for example, it employed 21 per cent of the total Catalan workforce in 1860, 47 per cent in 1930, and 18.4 per cent in 2014, despite the general de-industrialisation trend and global crisis (Domenech \& Ramos, 2016).

In Catalonia, development of agglomerated industries was first promoted by the industrial development policy of the 1960s. Since then, LIPS has been the most salient form of developing industrial areas and the economic reality of the region, especially since 1980s (Incasòl, 2007). Industrial activity, in general, represents almost 20 per cent of GDP in the region. There are more than 40 LIPS, including almost 9000 industrial establishments, generating turnover of more than 45 billion Euros, contributing to an estimated 10 per cent of the region's GDP (Hernández, et al., 2005). The region has been relatively active in sustainability-oriented initiatives because its rapid industrial development has surpassed the available land for further development. The intensity and diversity in geographically agglomerated industries have provided a proper ground for potential exchange synergies between industrial actors, which may create industrial ecosystems in the region.

We followed an embedded case study design with multiple units of analysis (Yin, 2014) - that is, various industrial symbiosis initiatives - to understand how these initiatives contributed to the emergence of regional industrial ecosystems. After a review of the literature, internet and research reports, we selected eight industrial symbiosis initiatives from the region, which have addressed sustainability transitions of LIPS in the region through their objectives and activities. Seven of these initiatives were completed, while the other is still on-going. The selected set of initiatives covers an 18-year time span, from 1999 to 2017. Temporal distribution of initiatives, together with their names, start and end years, are illustrated in Fig. 2 below. 


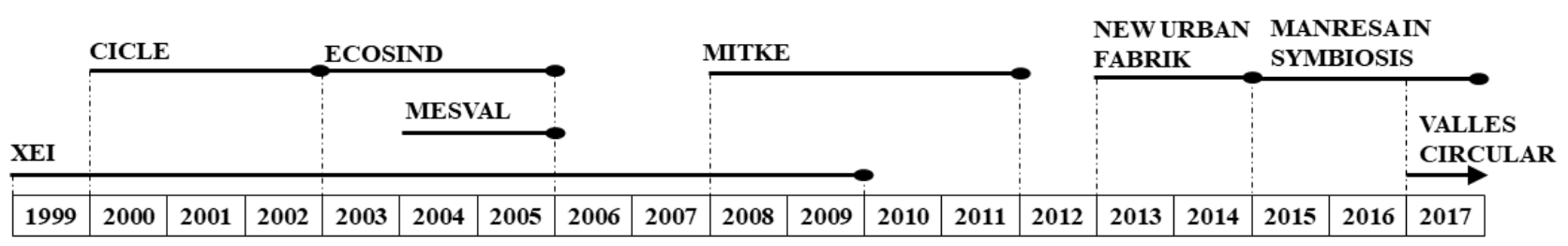

Fig. 2. Temporal distribution of eight industrial symbiosis initiatives under analysis from Catalonia over 18 years

After identifying these eight initiatives, we conducted interviewees and collected available secondary data from the interviewees and from online sources to develop an integrated set of interpretations (Yin, 2014) drawing upon our conceptual framework.

\subsection{Data and insight gathering}

This study is based on two different sources of empirical material, considering triangulation of the data and insights (Yin, 2014; Creswell \& Clark, 2007) to enhance the credibility of our research results while securing an in-depth understanding (Denzin \& Lincoln, 2005).

Firstly, secondary data related to industrial ecosystem development in Catalonia was used as a source of evidence to trace the related industrial development in the region. Collected secondary data includes comprehensive reports from governmental organisations, interim and final reports of selected local experiments, press releases, presentations, posters, articles, news and blogs published in the mass media or in community newspapers. All the secondary data was selected considering their source and scope (Hox $\&$ Boeije, 2005), their trustworthiness and their relevance to our research question. Secondary data inventory is given in Appendix A.

Secondly, semi-structured interviews were conducted with the most relevant actors in relation to the selected industrial symbiosis experiments from the region. We started our interviews with key informants who were involved in design and implementation of the initial experiments; during our interviews with them, we identified more key informants using the snowball technique (Lincoln \& Guba, 1985; Heckathorn, 2002) for other selected experiments. Finally, from May 2017 until October 2017, we conducted eight interviews with nine interviewees. All interviewees were involved in design and implementation of the selected experiments with key roles, such as manager, coordinator, expert, and principal architect. Thus, they were able to provide us with the holistic background, design, implementation and follow-up situation of the experiments. The interviews lasted between 35 and 90 minutes. All interviews were recorded after obtaining the consent of the interviewees. Follow-up enquiries were conducted by e-mail or telephone and further secondary documents were collected from the interviewees as well for the sake of triangulation. The interviewees are listed in Appendix B.

Here we recognise that although the relatively high number of industrial symbiosis initiatives were included in the study, more initiatives may have pictured a more robust regional perspective. Yet, we never claimed to present a set of regional truths and have instead looked for ways to understand the regional niche development processes, which may help further regional policy development or inspire other regional development agents. Moreover, more interviewees from each initiative could have provided more insights as input for our interpretation and discussion. However, the selected interviewees were selected in a way that all of them had key roles for selected initiatives and had extensive knowledge about 
the details of its development. Also, triangulation of data and insight sources have added more trustworthiness to our empirical study.

Regarding the design of semi-structured interviews, we had a priori framing of the underlying interview questions (Creswell, 2009), encompassing the underpinning conceptual elements of our framework. We formulated the questions to examine: (i) the background of the interviewee; (ii) general information about the routines of industrial production systems in the region (that is, the industrial actors and industrial composition/specialisation of the region, related regulations in the region, infrastructure, regional interest in sustainability); (iii) detailed information about the related initiative (that is, the expectations and visions of the actors, the achieved results and unexpected outcomes, if and how the initiative was in relation to other similar initiatives in the region, network building activities, the involved actors and their level of involvement, challenges and success factors encountered during the development of the initiative, learning-oriented activities and learning outcomes for different actors); and finally (iv) general information about the region in regard to other similar initiatives and other relevant actors based on the experience and the knowledge of the interviewee.

Moreover, we have tailored the questions in language that would be understandable by the interviewees (Meyer \& Ward, 2014). Still, interviewees were are also permitted to explain beyond the answers to the drafted questions in order to gather more insights without concrete constraints. It is also crucial to note that those interviews alternated between retrospective and prospective reflections of interviewees (Schultze \& Avital, 2011). More specifically, most of the interviewees firstly shared with us their past experiences and ideas - that is, retrospective reflections (Eisenhardt \& Graebner, 2007) - about the specific local experiments because seven of eight experiments were already completed (see Fig. 2), and also there were prospective reflections from those interviewees evolving during the interviews when they started envisioning ideal conditions for regional industrial ecosystem development based on their past experiences and shared those ideas with us. It is worth pointing out that we were aware of potential recall bias, which may be due to retrospective distortion (Miles, 1979). However, in this paper, we hold a sustainability transitions perspective with an evolutionary approach, which requires an analysis of various events distributed over a considerable time-span (Farla, et al., 2012) and this makes it necessary to gather and analyse retrospective data and insights. Therefore, in order to avoid this potential bias due to retrospective reflections for completed industrial symbiosis experiments, we shared the semi-structured interview questions with the interviewees in advance of the interviews, and during the interviews we gave them enough time to reflect and think before answering (Hassan, 2005). Furthermore, using secondary data considering triangulation also enabled us to scrutinise reflections and insights of the interviewees by means of multiple sources of evidence in order to allay the potential recall bias concerns (Gioia, et al., 2010).

\subsection{Data and insight analysis and interpretation}

In this step, we analysed the data and insights by means of codes and categories, and then interpreted the relationship among them through explanation building (Yin, 2014) to answer our research question. Firstly, we identified categories and codes based on the underpinning concepts of our conceptual framework; that is, the three niche internal processes that are articulations of expectations and visions, social network building and learning activities. Then, we further revised the coding scheme while analysing the data and insights, which led to the final list of codes and categories, as illustrated in Fig. 3. 


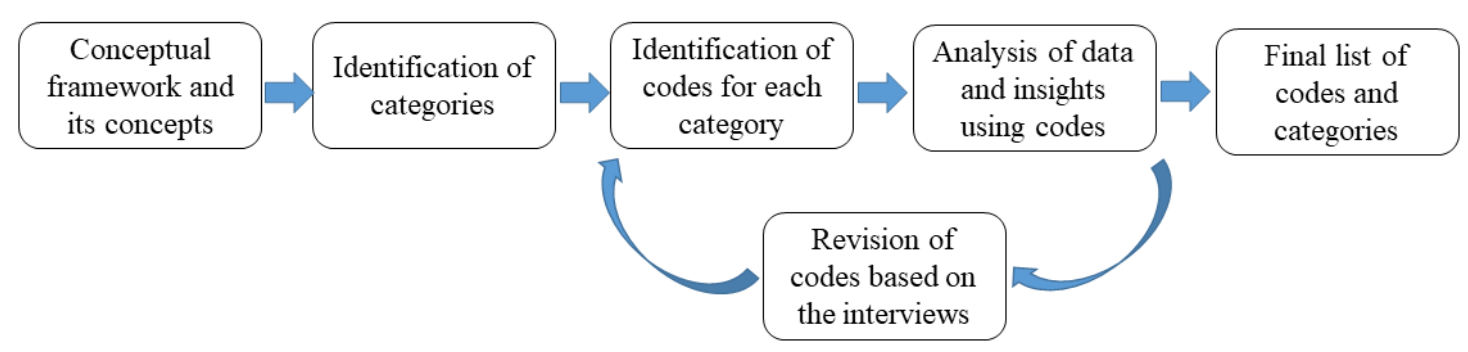

Fig. 3. Identification of codes and categories

Source: Authors' own elaboration.

Once the codes and categories were iteratively identified, we completed coding data and insights and allocated them to the relevant categories for each local industrial symbiosis experiment. We used the analytic technique of 'explanation building', which is a type of pattern matching (Yin, 2014), to observe the patterns and interpret the relationship among the codes in light of our conceptual framework to explain how each local industrial symbiosis experiment and its outcomes influenced three internal niche processes. Together, these can contribute to regional industrial ecosystem niche building for sustainability transitions of LIPS in Catalonia.

In the following section, we present how the emergence of regional industrial ecosystems can be understood and explained by analysing the identified prominent local industrial symbiosis experiments from the region and assessing their interlinkage and aggregating contribution to an emerging regional network of actors through coupled expectations and visions and shared cognitive, formal and normative rules.

\section{Results and discussions}

This section is structured based on the conceptual foundations of our framework to theoretically strengthen the understanding of regional industrial ecosystems' niche emerging dynamics. We start by describing the identified industrial symbiosis experiments that were implemented in Catalonia over the past two decades or so and analytically represent how those experiments have been interlinked (see Fig. 4). In Section 4.2, we present our assessment on the identified experiments' influence on regional niche building processes, which are the articulation of expectations and visions, social networking and learning activities. Subsequently, in Section 4.3, we discuss how those processes conduced towards the emergence of regional industrial ecosystems niche, and then represent our overall empirical assessment through operationalisation of our conceptual framework (see Fig. 5).

\subsection{Local industrial symbiosis experiments level}

In the region, industrial ecology and industrial symbiosis started to be discussed through the end 1990s at the academic level with efforts of some academicians from Universitat Autonoma de Barcelona (UAB) and Universitat Politècnica de Catalunya (UPC), Universitat de Girona (UdG) and Universitat Rovira i Virgili (URV) as the first bricks on the regional niche building wall. The first few experiments were initiated by academia in collaboration with related governmental organisations, followed by various other experiments.

In this paper, we analysed the local industrial symbiosis experiments level through a selected set of eight industrial symbiosis experiments covering a period of 18 years starting from 1999 and coming up till 2017. 
Table 1 gives an overview of each experiment with its name, dates, objective, initiator and related important actors and their roles.

Table 1

Overview of analysed industrial symbiosis projects

\begin{tabular}{|c|c|c|c|}
\hline $\begin{array}{l}\text { Experiment } \\
\text { and dates }\end{array}$ & Objective & Initiator & Important actors \\
\hline $\begin{array}{l}\text { XEI } \\
1999-2009\end{array}$ & $\begin{array}{l}\text { To build a thematic network of } \\
\text { industrial ecology, aiming to } \\
\text { involve academia, industry and } \\
\text { policy-makers. }\end{array}$ & $\begin{array}{l}\text { UAB, UPC, UdG } \\
\text { and URV }\end{array}$ & $\begin{array}{l}\text { Financially supported by Department of } \\
\text { Universities, Research and Information } \\
\text { Society (DURSI) of the Government of } \\
\text { Catalonia at that time. }\end{array}$ \\
\hline $\begin{array}{l}\text { CICLE } \\
2000-2002\end{array}$ & $\begin{array}{l}\text { To identify the concrete } \\
\text { possibilities of applying industrial } \\
\text { ecology in Catalonia focusing on } \\
\text { leather and paper industries. }\end{array}$ & UPC & $\begin{array}{l}\text { Financially supported by Waste Agency of } \\
\text { Catalonia. }\end{array}$ \\
\hline $\begin{array}{l}\text { ECOSIND } \\
2003-2006\end{array}$ & $\begin{array}{l}\text { To foster sustainable development } \\
\text { of industrial production systems } \\
\text { based on industrial ecology } \\
\text { principles for Catalonia and other } \\
\text { partner regions from Italy and } \\
\text { Greece. }\end{array}$ & $\begin{array}{l}\text { Ministry of } \\
\text { Environment of } \\
\text { Government of } \\
\text { Catalonia as } \\
\text { consortium leader }\end{array}$ & $\begin{array}{l}\text { Designed by XEI members (mainly by UAB } \\
\text { and UPC); funded by Interreg Programme } \\
\text { of European Commission. }\end{array}$ \\
\hline $\begin{array}{l}\text { MESVAL } \\
2004-2006\end{array}$ & $\begin{array}{l}\text { To build a new industrial ecology } \\
\text { network between technological } \\
\text { centres, chambers of commerce, } \\
\text { and the universities from Catalonia, } \\
\text { Tuscany (Italy) and Peloponnesus } \\
\text { (Greece). }\end{array}$ & Coordinated by UPC. & $\begin{array}{l}\text { Funded by ECOSIND budget as a sub- } \\
\text { project. }\end{array}$ \\
\hline $\begin{array}{l}\text { MITKE } \\
2008-2011\end{array}$ & $\begin{array}{l}\text { To retrofit existing business and } \\
\text { industrial areas and transforming } \\
\text { them into sustainable spaces in the } \\
\text { partner regions. }\end{array}$ & $\begin{array}{l}\text { Catalan Land } \\
\text { Institute (Incasòl) as } \\
\text { a consortium partner }\end{array}$ & $\begin{array}{l}\text { Funded by Interreg Programme of European } \\
\text { Commission; consortium leader as Sprilur } \\
\text { which is LIPS Development Agency of } \\
\text { Basque Country in Spain }\end{array}$ \\
\hline $\begin{array}{l}\text { New Urban } \\
\text { Fabrik } \\
\text { 2013-2014 }\end{array}$ & $\begin{array}{l}\text { To evaluate the feasibility of } \\
\text { transforming Torrent Estadella (old } \\
\text { LIPS) into an eco-industrial park. }\end{array}$ & $\begin{array}{l}\text { Barcelona City } \\
\text { Council }\end{array}$ & $\begin{array}{l}\text { Prepared by Eduard Balcells Architecture, a } \\
\text { private architecture company }\end{array}$ \\
\hline $\begin{array}{l}\text { Manresa in } \\
\text { Symbiosis } \\
2015-2017\end{array}$ & $\begin{array}{l}\text { To implement the first applied } \\
\text { industrial symbiosis project in } \\
\text { Catalonia to maximize efficiency in } \\
\text { the use of available resources. }\end{array}$ & $\begin{array}{l}\text { The municipality of } \\
\text { Manresa and Waste } \\
\text { Agency of Catalonia }\end{array}$ & $\begin{array}{l}\text { Run by Simbiosy, a regional private } \\
\text { consultancy company as the project } \\
\text { consultant; supported and facilitated by } \\
\text { Bages Consortium of Waste Management } \\
\text { and Department of Territory and } \\
\text { Sustainability of Regional Government of } \\
\text { Catalonia. }\end{array}$ \\
\hline $\begin{array}{l}\text { Vallès } \\
\text { Circular } \\
2017- \\
\text { ongoing }\end{array}$ & $\begin{array}{l}\text { To promote circular economy by } \\
\text { building networks in the territory in } \\
\text { order to take advantage of new } \\
\text { ways of industrial production and } \\
\text { also consumption. }\end{array}$ & $\begin{array}{l}\text { The Vallès } \\
\text { Occidental County } \\
\text { Council }\end{array}$ & $\begin{array}{l}\text { Supported by Government of Catalonia and } \\
\text { the Barcelona City Council. }\end{array}$ \\
\hline
\end{tabular}

The local experiments level in Catalonia showed characteristics of both top-down and bottom-up development characteristics, in both cases aiming to establish connections between academia, governmental organisations and industry. Data and insights revealed that those connections resulted in fruitful interactions that led to considerable linkages between local experiments in the region.

$\mathrm{XEI}$, as the first experiment, was created and initiated by actors from the academia in the region, which had leading roles as niche players. The same players from these universities and research institutes also had direct roles in terms of designing, lobbying and networking for the creation of CICLE, ECOSIND, and MESVAL experiments, although these three were initiated by governmental organisations through regional or international funding. Another experiment, MITKE was also started by a regional governmental organisation and was linked to another experiment, ECOSIND, through which MITKE coordinators from Catalonia had learnt ways of starting such experiments in terms of fundraising and 
international partnering. Although Manresa in Symbiosis was triggered and implemented by a private niche player, it had the support of governmental organisations and it drew upon previously gained knowledge in Manresa through the MESVAL experiment. Finally, Vallès Circular, the recently started and on-going experiment, is a county-based circular economy initiative that has been developed based on the knowledge of the actors and experience of the region coming from previous experiments, such as XEI, CICLE, ECOSIND and MESVAL. Analytical illustration of these linkages between niche experiments is presented below in Fig. 4. Only New Urban Fabrik experiment is missing in this figure as this was an early-phase experiment and differs from others because it was not implemented. It was included in this paper to reflect the importance of power issue in sustainability transitions, which is discussed later in Section 4.3.1. Those interlinkages between the experiments show clues of emerging regional industrial ecosystem niche level in the region. We further elaborate on this in the next section through analysis of local experiments' contribution to three niche building processes.

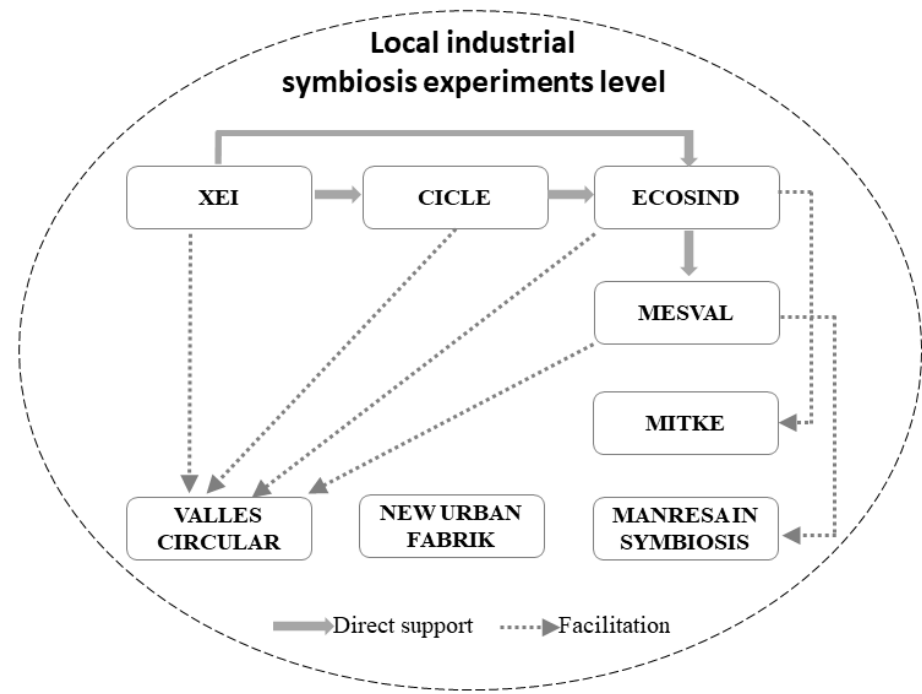

Fig. 4. Interlinkages between local industrial symbiosis experiments

\subsection{Experiments' influence on regional niche building processes}

Data and insights showed that each industrial symbiosis experiment contributed, to some extent, to regional niche building processes. Table 2 summarises the changing characteristics of niche processes in each experiment and is further explained through our following discussions on each niche process separately.

Table 2

Overview of internal niche processes for each experiment

\begin{tabular}{|c|c|c|c|}
\hline Experiment & Expectations and visions & Social network building & Learning \\
\hline XEI & $\begin{array}{l}\text { Positive and high-level expectations } \\
\text { on network building through a } \\
\text { knowledge exchange platform. No } \\
\text { common vision of what industrial } \\
\text { ecology meant. }\end{array}$ & $\begin{array}{l}\text { A thematic network of regional } \\
\text { actors including researchers, } \\
\text { universities, governmental } \\
\text { organisations and industry. } \\
\text { Involvement in related } \\
\text { international academic societies. }\end{array}$ & $\begin{array}{l}\text { Facilitation of knowledge and } \\
\text { experience exchange through } \\
\text { events. Learning outcomes for } \\
\text { industrial actors and } \\
\text { governmental actors that led to } \\
\text { cultivation for CICLE and } \\
\text { ECOSIND. }\end{array}$ \\
\hline CICLE & $\begin{array}{l}\text { Positive and medium-level } \\
\text { expectations to uncover the } \\
\text { potential of industrial ecology in the } \\
\text { region. }\end{array}$ & $\begin{array}{l}\text { Network building activities for } \\
\text { recycling bodies and industrial } \\
\text { actors. }\end{array}$ & $\begin{array}{l}\text { Second-order learning for } \\
\text { industries and recycling bodies. } \\
\text { Learning outcome for Waste } \\
\text { Agency of Catalonia, which } \\
\text { was a supporter of ECOSIND. }\end{array}$ \\
\hline ECOSIND & Positive and high-level expectations & A consortium of international & Knowledge transfer to \\
\hline
\end{tabular}




\begin{tabular}{|c|c|c|c|}
\hline Experiment & Expectations and visions & Social network building & Learning \\
\hline & $\begin{array}{l}\text { to establish a new regional } \\
\text { industrial symbiosis strategy. } \\
\text { Difficulty in having common } \\
\text { expectations among international } \\
\text { partners of the project. Blurred } \\
\text { vision about the new and relatively } \\
\text { radical practice - that is, industrial } \\
\text { symbiosis - for regional } \\
\text { governmental organisations and the } \\
\text { industry. }\end{array}$ & $\begin{array}{l}\text { partners directly leading to cross- } \\
\text { national networking between } \\
\text { Spain, Italy and Greece. Loose } \\
\text { network among related regional } \\
\text { actors such as the Union of } \\
\text { Catalan Industrial Estates (UPIC), } \\
\text { Catalan Land Institute (Incasòl) } \\
\text { and the industry. }\end{array}$ & $\begin{array}{l}\text { governmental organisations } \\
\text { and the industry through } \\
\text { events. Cultivation for } \\
\text { MESVAL through direct } \\
\text { funding. Cultivation for } \\
\text { MITKE initiative through } \\
\text { knowledge sharing with } \\
\text { Incasòl. Failed second-order } \\
\text { learning for the industry. }\end{array}$ \\
\hline MESVAL & $\begin{array}{l}\text { Positive and medium-level } \\
\text { expectations for a new industrial } \\
\text { ecology network in the region with } \\
\text { a vision to create a regional waste } \\
\text { recovery strategy. }\end{array}$ & $\begin{array}{l}\text { Initiating a cross-regional and } \\
\text { cross-national network of } \\
\text { technological centres, chamber of } \\
\text { commerce and universities of } \\
\text { three regions from Spain, Italy } \\
\text { and Greece. }\end{array}$ & $\begin{array}{l}\text { Learning within the cross- } \\
\text { regional network through } \\
\text { knowledge exchange events. } \\
\text { Learning for local actors in } \\
\text { Manresa, which then facilitated } \\
\text { Manresa in Symbiosis. }\end{array}$ \\
\hline MITKE & $\begin{array}{l}\text { Positive and high-level expectations } \\
\text { for retrofitting existing regional } \\
\text { industrial areas and transforming } \\
\text { them into sustainable spaces. } \\
\text { Common vision among } \\
\text { international partners for creating } \\
\text { region-tailored solutions. Lack of } \\
\text { regional consciousness of } \\
\text { "industrial symbiosis". }\end{array}$ & $\begin{array}{l}\text { Cross-regional and cross-national } \\
\text { networking between } 11 \text { partners } \\
\text { including regional development } \\
\text { agencies, business networks and } \\
\text { land developers and research } \\
\text { centres from Basque Country, } \\
\text { Catalonia, and regions of seven } \\
\text { other countries. A pan-European } \\
\text { platform for retrofitting existing } \\
\text { LIPS. }\end{array}$ & $\begin{array}{l}\text { Knowledge sharing and co- } \\
\text { creation based on best- } \\
\text { practices among international } \\
\text { partners. Second-order learning } \\
\text { outcomes for Incasòl in terms } \\
\text { of planning a follow-up project } \\
\text { and, more importantly, an } \\
\text { institutional change. }\end{array}$ \\
\hline $\begin{array}{l}\text { New Urban } \\
\text { Fabrik }\end{array}$ & $\begin{array}{l}\text { Neutral and medium-level } \\
\text { expectations on potential } \\
\text { transformation of an old LIPS, into } \\
\text { an eco-industrial park. Interrupted } \\
\text { and changed expectations due to } \\
\text { change in power actors. }\end{array}$ & $\begin{array}{l}\text { No network building activity } \\
\text { except the established relations } \\
\text { between the actors in Barcelona } \\
\text { City Council and the consultancy } \\
\text { team. }\end{array}$ & $\begin{array}{l}\text { Ineffective first-order learning } \\
\text { for the governmental } \\
\text { organisation; that is, no } \\
\text { outcome from the experiment. }\end{array}$ \\
\hline $\begin{array}{l}\text { Manresa in } \\
\text { Symbiosis }\end{array}$ & $\begin{array}{l}\text { Positive and high-level expectations } \\
\text { to realise real symbiotic exchanges } \\
\text { and become a success } \\
\text { demonstration story for future } \\
\text { related experiments. Lack of } \\
\text { territorial vision despite gained } \\
\text { previous knowledge in MESVAL. }\end{array}$ & $\begin{array}{l}\text { Good communication with } \\
\text { sensible local and regional actors } \\
\text { through network building. } \\
\text { Lobbying activities for bringing } \\
\text { protection and support to start, } \\
\text { implement and follow-up the } \\
\text { initiative. }\end{array}$ & $\begin{array}{l}\text { First-order learning for the } \\
\text { industry and governmental } \\
\text { organisations on how to launch } \\
\text { such experiments. Mining out } \\
\text { previous knowledge in } \\
\text { Manresa gained through } \\
\text { previous experiments, such as } \\
\text { MESVAL. Second-order } \\
\text { learning for the industry by real } \\
\text { symbiotic exchanges. }\end{array}$ \\
\hline $\begin{array}{l}\text { Vallès } \\
\text { Circular }\end{array}$ & $\begin{array}{l}\text { Positive and high-level expectations } \\
\text { and vision for promoting circular } \\
\text { economy in Vallès Occidental } \\
\text { County to become a reference } \\
\text { circular economy territory that will } \\
\text { serve as a branding instrument. }\end{array}$ & $\begin{array}{l}\text { Network building experiment by } \\
\text { its objectives. An agreement } \\
\text { signed by } 30 \text { entities, including } \\
\text { municipalities, universities, } \\
\text { research centres, business } \\
\text { organisations, and industry. }\end{array}$ & $\begin{array}{l}\text { Regional learning through } \\
\text { dissemination activities and } \\
\text { events in the network. }\end{array}$ \\
\hline
\end{tabular}

\subsubsection{Articulation of expectations and visions}

Even before the first local industrial symbiosis experiment, XEI, there had already been an established common ground about the need for sustainable development in the region. However, introducing industrial ecology as a new concept to the academic environment in Catalonia and as a new policy and development tool to the region was a difficult task for the creators and coordinators of the XEI. There was no vision among different actors in the region about what industrial ecology actually meant and how it could address sustainability problematic of LIPS. In this vein, the co-creator and member of XEI stated:

\footnotetext{
"It was not easy to start industrial ecology in Catalonia. We were trying to inform several regional actors why industrial ecology was important and how it was different than other sustainable development actions ... But it was very difficult to convince them ... For example, if the industry
} 
doesn't see any immediate economic profit, they normally do not get involved. And the mentality of the governmental institutions was not really open to new concepts."

Since XEI was initiated in 1999, a sequence of industrial symbiosis experiments has been implemented and a regional understanding of industrial ecology has been established, although those experiments were conducted through varying expectations and visions and resulted in different achievement levels.

Relatively large-scale experiments, in terms of a bigger budget, a higher number of partners and longer duration like ECOSIND and MITKE, were initiated by the regional governmental organisations, which had positive and high expectations from the beginning that were not easy to achieve. In the ECOSIND case, for example, once the experiment was started it was challenging to create a common understanding even within the regional Catalan ministry and to engage the industry in the experiment due to lack of experience in similar initiatives. The outcomes of the experiment demonstrated the importance of having a common vision and expectation for the involved actors. Based on his experience, the experiment coordinator noted, with regret:

"If I started ECOSIND now, as the public servant that I am, I would try to put all people in charge from all Departments on the same table and start the project together... Now I know the methodology. First thing is to put all the departments with the same vision and try to achieve a governance model in order to go in the same direction. Another step is to integrate industry in this initiative. We already have a lot of experience here in Catalonia combining private and public sector with the same visions ... We have experience and frameworks to achieve this."

On the other hand, the data and insights related to the MITKE experiment revealed that there was a lack of regional consciousness of "industrial symbiosis". In the experiment, neither industrial symbiosis nor eco-industrial park terminology was used in terms of its vision, although they were among its core expectations. As the project development coordinator of Incasòl stated:

"We did not call it industrial symbiosis in the project, although we were with it all the time now we see it... For us, it is the fact of the collaboration between LIPS or the companies. Industrial symbiosis, now we see it, was an ideal that we were trying to get to."

Unlike those experiments, CICLE, designed by XEI core members, was the first local experiment to facilitate real symbiotic exchanges between industrial actors. Its vision was to learn the concrete possibilities of applying industrial ecology in Catalonia. Among the other analysed experiments, only one - Manresa in Symbiosis - had a similar vision regarding facilitation of real symbiotic exchanges, but on a smaller scale; namely, in Manresa. The local actors in the city already had knowledge background of what an industrial ecosystem would mean by means of another experiment, MESVAL. However, Manresa in Symbiosis, despite the local previous knowledge and familiarity gained through MESVAL, still faced with difficulties to convince especially the industry to get involved in the network of exchanges.

Among the set of analysed experiments, The New Urban Fabrik was an interesting example reminding the issues of power. The vision and expectations of the Barcelona City Council changed after the party in power changed and this led to the failure of the initiative and interrupted its implementation. Indeed, as Truffer and Coenen (2012) stated, "sustainability transitions are by their very nature political projects" and transition processes might change based on the change in interests of specific power actors or on the change of power actors themselves, as was the case for this experiment. The principal architect of the experiment explained this as: 
"... Then the political government changed ... When we went to the new responsible for the urban design and they said the project was still interesting, but the new City Council was more focused on social housing building. Our project was not prioritised. In the end, it was a more like a research proposal and, at a certain moment, there had been a will to realise it. Of course, a real application would require a policy support..."

The last experiment, Vallès Circular, is a territorial circular economy initiative and is protected by governmental organisations through articulated expectations and visions from previous experiments, such as XEI, CICLE, ECOSIND and MESVAL. Industrial symbiosis is covered in its vision in relation to the creation of a public-private collaboration ecosystem and the recognition of companies and entities that act as agents of change. This implies a vision shift in the region. The circular economy, as a bigger umbrella concept for industrial ecology, is becoming a promising and more popular policy tool for the regional industrial development. This may be due to its clear emphasis on 'economy' although the core emphasis is on the resource scarcity same as industrial symbiosis. One of our interviewees, UAB professor, co-creator and member of Vallès Circular, explained this as follows:

"Now, the circular economy concept has more power. At this moment the symbiotic relations, or the idea, philosophy behind the symbiotic relations are included in circular economy development here in Catalonia."

\subsubsection{Social network building}

Network building has been a crucial activity for the analysed experiments, except the New Urban Fabrik experiment, which only established relations between the actors in Barcelona City Council and the consultancy team. Regional network building was started with XEI experiment, which facilitated a thematic network of industrial ecology composed of researchers, universities, the industry, and governmental organisations. The network worked continuously to include more members to raise regional awareness. Furthermore, co-creators of XEI from academia were also members of International Society for Industrial Ecology (ISIE) and as such, they acted as knowledge bridges between the region and ISIE.

Network building activities were not limited only to the regional actors but also were achieved at the crossregional and cross-international level in the experiments that were implemented by international consortiums; that is, ECOSIND, MESVAL and MITKE. Those experiments, by their visions and expectations more related to planning and strategy making, established links between universities, governmental and non-governmental organisations and, to some extent, the industry. Thus, the industrial symbiosis network, based on the symbiotic exchanges, did not emerge and there was a minimal involvement from the regional industrial actors in those experiments.

On the other hand, applied industrial ecology-oriented experiments like CICLE and Manresa in Symbiosis revealed the crucial role of the industry and facilitated concrete relationships between regional actors and the industry. CICLE had positive results in terms of realising some pilot symbiotic exchanges between industrial actors and it enabled information exchange between recycling bodies and the industry. Trust was the common issue in both experiments and it was difficult to convince industrial actors to share information and become involved in the initiatives. The project team of Manresa in Symbiosis worked individually with various industries to identify potential synergies that would motivate the industry's willingness to participate. The coordinator of the project underlined that: 
"...firstly we identified the most sensible actors from the region to realise this project. Then we worked as activators to start it..."

The results of Manresa in Symbiosis showed that in only a year and a half, 27 companies have participated, 50 businessmen and technicians have been involved and eight synergies, four of which are in implementation, have been identified. Although the official contract has ended, the project coordinator said:

"An industrial symbiosis project never ends... It is a continuous process..."

In line with this, the project team continued lobbying and networking to have further support from the governmental organisations to ensure the continuation of the experiment. The Waste Agency of Catalonia continues to financially contribute to the promotion of industrial symbiosis in Manresa.

Finally, Vallès Circular was initiated in 2017 through the efforts of County Council to bring together actors from earlier niche experiments such as XEI, CICLE, ECOSIND and MESVAL. The agreement includes 11 of 23 local municipalities from the County, as well as other regional and local actors like Department of Territory and Sustainability from the Government of Catalonia, Barcelona City Council, Waste Management Agency of Vallès Occidental, business organizations, chambers of commerce, universities, and industry.

\subsubsection{Learning activities}

We distinguished learning outcomes from all experiments, except the New Urban Fabrik experiment, which was interrupted and not implemented due to change in power actors, as explained above. Starting with the XEI experiment, the thematic network creators and members organised various communication events, including meetings, workshops, forums, conferences, and seminars for knowledge exchange within the network and for bringing in new network members. The actors from governmental organisations who became directly involved in these learning events mainly had technical responsibilities in their home organisations, but they still acted as learning facilitators for other institutional actors who had more political power to initiate new experiments. Furthermore, co-creators of XEI from academia were also members of the International Society for Industrial Ecology (ISIE) and, as such, they acted as knowledge bridges between the region and ISIE. There was reciprocal learning as these academicians were sharing what they learnt from ISIE based on international experiences with the regional actors and they were also explaining the existing situation in Catalonia to the ISIE.

The CICLE experiment was a learning outcome of XEI as it was initiated through the funding from Waste Agency of Catalonia, which had gained relevant knowledge from XEI communication events. CICLE, with its vision towards applied industrial ecology in the region, managed to activate industries and recycling bodies by means of facilitating their involvement in pilot symbiotic exchanges. Thus, it was one of the few experiments that may be considered to have provided a second-order learning outcome for the industry through real implementations (Schot \& Geels, 2008).

ECOSIND was initiated after almost three years of preparation by XEI members together with the Ministry of Environment of Government of Catalonia. Knowledge dissemination and learning activities from XEI, and also raising awareness achieved by the CICLE Project, were the main triggers for starting this experiment. By means of communication events, ECOSIND helped other regional actors to learn, especially from Italian partners of the experiment that had already been active in implementing industrial 
symbiosis projects. They learnt that collaboration with the industry was key to achieving good results from such experiments. However, there was a limited interest from the Catalan industry in ECOSIND due to missing exemplary successful industrial symbiosis cases in the region. As also stated by the UAB professor who was the co-creator of XEI and an expert in ECOSIND:

"A small set of regional demonstrative successful actions were what we needed. Not only one big industrial ecosystem experiment ... We needed a critical mass of actions in different industrial sectors at different regional locations. Disseminating these small-scale but well-done examples through mass media could attract the industry."

Although ECOSIND did not achieve a set of applied industrial ecology actions, it did lead to other regional projects. MESVAL was one of the sub-projects funded by the ECOSIND. The main beneficiary was Manresa city in Bages County. The MESVAL team not only evaluated and reported the industrial ecosystem development potential of Manresa but also built local awareness for local actors through the exchange of knowledge and expertise between international partners. Local actors in Manresa developed a local knowledge background for what an industrial ecosystem would mean and what to expect from such an experiment through learning.

This learning outcome later facilitated the Manresa in Symbiosis experiment at the governmental level. However, despite having a previous knowledge and familiarity with practices of industrial symbiosis, it was still difficult to convince the industry to get involved in the network of exchanges. Again a small set of successful demonstrative industrial symbiosis exchanges were missing to attract the industry. Manresa in Symbiosis fulfilled this gap and created second-order learning outcomes for local industry through practising physical and non-physical symbiotic exchanges between industrial actors.

Another second-order learning outcome from local industrial symbiosis experiments level was for a governmental organisation, Incasòl, which was motivated through ECOSIND for initiating a new experiment using similar funding mechanisms and designed MITKE experiment. This experiment served as a learning platform and provided mechanisms for the collection, exchange and transfer of knowledge using the potential of its crowded international consortium. At the communication events organised during MITKE, Incasòl had the opportunity to draw upon synergies between different regional actors while coworking with them to create a management model for LIPS. The organisation learned that such a management model would require government involvement in the whole process. Yet, Incasòl did not have any direct responsibilities or even possible roles in LIPS management, and in fact, it may have had a crucial role in promoting and facilitating industrial symbiosis in LIPS development. The head of the Environment Department explained this as follows:

“...We are trying to incorporate the knowledge that has been acquired from MITKE ... What we have learnt is that industrial symbiosis is within the LIPS management and it cannot be thought separately ... Luckily, there has been a desire among all parties to promote some regulatory changes. In fact, we are now in a moment of change, that we should take advantage of the changes in urban planning law with respect to approval of a new law that we call the Law of Territory, so that Incasol may have direct or indirect involvement in LIPS management."

Moreover, Incasòl signed an agreement in 2008 with the local government of Camí dels Frares in Lleida for Camí dels Frares Industrial Park. After learning from the best practices from other member regions of MITKE project, Incasòl had the opportunity to implement its knowledge by conducting pilot work on integral management of services of this LIPS. 
Finally, Vallès Circular stands as a learning outcome of XEI, CICLE, ECOSIND, and MESVAL experiments and implements regional learning by extending its agreement network and continuous knowledge dissemination and communications events.

\subsection{Regional industrial ecosystems niche level}

In our conceptual framework, this level is characterised by coupled expectations and visions; shared cognitive, formal and normative rules; and regional network of actors. Thus, discussions on this level are central to understand how industrial symbiosis initiatives can contribute to the emergence of regional industrial ecosystems for sustainability transitions of LIPS.

Thus far, we have analysed the local industrial symbiosis experiments and presented their influence on each regional niche building processes. We now synthesise the obtained results to discuss the aggregation of these processes, which shed light on empirical assessment of regional industrial ecosystems niche in Catalonia, as illustrated in Fig. 5.

Empirical data and insights from Catalonia provided clues to observe a regional endogenous and gradual steering for emerging regional industrial ecosystems through regional networking, which demonstrated a collective representation (e.g. Schot \& Geels, 2008) involving various regional actors: regional and local governmental organisations, researchers, universities, private consultancy companies, regional development agencies, and industry. The built networks as the outcome of experiments varied in structure, in terms of involved actors, and in dynamics, in terms of collaboration processes for each experiment. Considering those networks, it can be concluded that a regional network of actors has been emerging in Catalonia.

Based on characteristics and results of local industrial symbiosis experiments, it is still hard to mention about shared expectations and visions among relevant regional actors. Nevertheless, continuously cultivated experiments have been interacting in different ways and influencing each other's objectives and outcomes through couplings. One common expectation and vision can be pictured for networking building, which then facilitated learning processes in industrial symbiosis experiments. These learning processes afterwards conveyed expectations and visions to regional actors, which then turned out to be niche actors for the upcoming experiments in the region. In other words, the local experiments have been directly supporting or influencing each other by means of learning outcomes.

A crucial shortcoming of most experiments was the minimal involvement of the industry. Cognitive and normative frames of LIPS actors were not truly aligned into industrial ecosystem principles. Moreover, we have not observed concrete changes in formal rules such as tax regime, environmental regulations, or market mechanisms that could facilitate changes in cognitive and normative frames of the LIPS. Niche experiments have not yet totally fitted into the existing industrial production routines and have mostly provided first-order learning outcomes for the industry. For transitions to occur, there is still a need to change the production routines; this could be achieved by second-order learning through real implementations, as also suggested by the SNM studies (Schot \& Geels, 2008; Boon, et al., 2014). There is also still a need for a demonstrative set of real successful exchange experiments in the region. In these concerns, regional champions or coordinating bodies may have been helpful in line with previous empirical findings from industrial ecology literature (Hewes \& Lyons, 2008; Domenech \& Davies, 2011) but we have not identified any of them in the region based on the collected data and insights for this paper. 


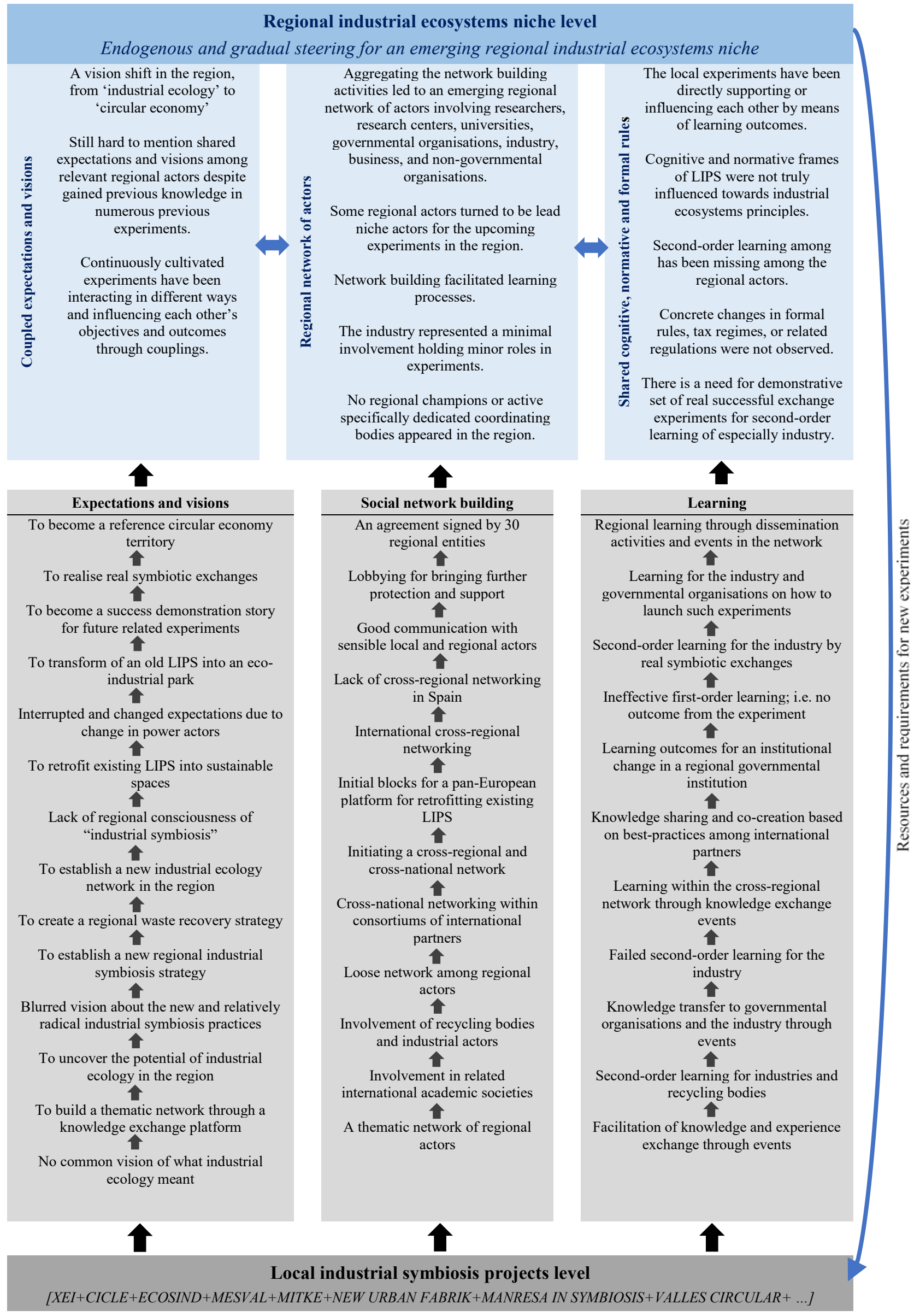

Fig. 5. The emergence of regional industrial ecosystems niche in Catalonia 
Another remark from the results is related to lack of cross-regional networking in Spain. It was only in MITKE experiment that two regions from Spain collaborated. If learning processes in Catalonia are aggregated and cross-regionally transferred, the industrial production routines at other autonomous regions in Spain may gradually change into more circular ways, and vice versa. Experiences and knowledge of other regions may contribute to further niche development and stabilisation in Catalonia as well.

Overall, it can be stated that the outcomes of continuously cultivated local niche experiments in Catalonia have crucially contributed to three internal niche processes. However, there is still a way to go for regional industrial ecosystem niche building. While social network building processes have led to a promising emerging community, more industrial actors need to be involved in the regional network. On the other hand, learning processes of the local experiments have provided important learning outcomes for different actors, which then directly supported or facilitated new experiments. Yet, second-order learning is still missing, especially for the industrial actors. The results of this study pointed to the required conditions that would better encourage the industry for real symbiotic exchanges, which could influence their cognitive and normative rules that form the basis for future sustainability transitions of LIPS. Moreover, second-order learning was observed only in one governmental organisation, which after the experiment (MITKE) has been trying to change the underlying rules of the existing problematic situation related to formal rules. In brief, if a broader regional network, including the industry, with more second-order learning outcomes, can be achieved in the region, then it will be possible to talk about a regional industrial ecosystems niche with coupled expectations and visions towards a common direction for sustainability transitions of LIPS. Finally, our case study revealed that the emergence of regional industrial ecosystems niche for sustainability transitions of LIPS does not exclusively depend on articulation of expectations and visions, network building or learning activities, but eventually the dynamic interaction between all three niche processes.

\section{Conclusion}

In this paper, we aimed to understand how industrial symbiosis initiatives can contribute to the emergence of regional industrial ecosystems for sustainability transitions of LIPS. To do so, firstly we attempted to enlarge the visionary window of the industrial ecology research by building on SNM framework and its concepts. Integrating industrial ecology literature and SNM, we developed a framework that provides a conceptual foundation for analysing and understanding regional industrial ecosystem development by focusing on the interaction of two heuristic and analytical levels - that is, the local industrial symbiosis experiments level and the regional industrial ecosystems niche level - linked through three analytical niche processes as suggested by the SNM perspective. The developed framework provides grounds for a structured and diversified analysis of individual industrial symbiosis initiatives and their aggregating contribution to the emergence dynamics of regional industrial ecosystems.

Our empirical study, with data and insights from Catalonia, demonstrated how a set of local industrial symbiosis experiments can be analysed to understand the emergence of regional industrial ecosystems using our conceptual framework. The results showed that continuously cultivated and interlinked industrial symbiosis initiatives from the region have been gradually adding up to an emerging regional industrial ecosystems niche. However, it is not yet accurate to speak of a broad emerged community with articulated expectations and visions and shared cognitive, formal and normative rules. In this vein, 
continuity of local industrial symbiosis experiments is crucial to keep the momentum going, as also suggested by the SNM studies (Raven, 2005; Schot \& Geels, 2008), to involve more industrial actors in the regional network; to develop more real symbiotic exchanges for second-order learning of the industry; to assign regional coordinators with an industrial ecology vision; to create deeper linkages between experiments; and to inform more actors in the region about what has been achieved so far and the necessary future steps. If emerging regional network provides support and protection for new experiments, which will continuously contribute to regional niche building processes, a regional culture change can be realised to achieve sustainability transition of LIPS employing closed industrial production loops.

Our theory-driven approach in this paper is not to test, verify or expand the SNM framework. Instead, it should be seen as an endeavour to link industrial ecology to innovation studies and to bring in issues from ST field of innovation studies into the industrial ecology literature through synthesising a conceptual framework. Our framework advances the richness of the industrial ecology field through using different concepts (niche experiments, niche building, articulation of expectations and visions, first-order and second-order learning, emerging community, etc.) and, more importantly, making different lines of interpretations (local industrial symbiosis initiatives as niche experiments gradually aggregating into regional industrial ecosystems niche). While distinguishing different levels of analysis and conceptualising their interactions through proposed processes, we did not aim to provide ontological descriptions of reality; instead, we generated analytical and heuristic concepts that could guide us to understand and explain the complex dynamics of potential emergence of regional industrial ecosystems in real settings.

Therefore, our empirical study not only addressed our research question but also served to explore the plausibility of our conceptual framework rather than testing, verifying or expanding it. Adopting a case study strategy, we illustrated the merits of our conceptual approach and provided an analytical narrative on emerging regional industrial ecosystems in the selected region covering an 18-year period. Our narrative has been guided by the main concepts of our framework, which enabled us to draw an analytical illustration (see Fig. 5 in Section 4.3) and enables the interpretive explanations for understanding the individual industrial symbiosis experiments, the interplay between them, and their aggregating contribution to the emerging regional network of actors through coupled expectations and visions and shared cognitive, formal and normative rules.

In this paper, we have conferred theoretical, methodological and empirical contributions. Firstly, we developed a conceptual framework that provides a conceptual structuration of two interconnected heuristic and analytical levels. It enables the analysis of separate but gradually adds up industrial symbiosis experiments and their contribution to the emergence of regional industrial ecosystems through three analytical niche building processes for sustainability transitions of industrial production systems. Secondly, we differ from most case studies in industrial ecology literature in that we focused on a set of local industrial symbiosis experiments. We focused on each experiment as a separate unit of analysis and then combined and synthesised their results to understand their aggregating influence on the emergence of regional industrial ecosystems. As for empirical contributions, we provided new understandings based on new data and insights from the Catalonia region, which has never been analysed in industrial ecology literature. Moreover, the empirical study from Catalonia enabled the illustration of theoretical linkages between the concepts suggested by our framework in a real setting, which may help to analyse other relevant contexts in future studies with a refined or the same conceptual approach as ours. 
Considering practical and policy implications, the developed conceptual framework has been used in this paper as an analytical lens for ex-post evaluation (Schot \& Geels, 2008) of industrial ecosystem development in a region, but it can also be extended as a prescriptive management tool for regional actors from Catalonia, as well as other regions holding an interest in initiating or sustaining industrial symbiosis initiatives. More specifically, if new experiments can be designed from the beginning considering the internal niche building processes using our framework prescriptively as a management tool, then their contribution to regional industrial ecosystems niche can be stronger, as also suggested by the SNM literature (Weber, et al., 1999; Raven, 2006; Schot \& Geels, 2008). Moreover, this paper also contributes to better understanding of complex dynamics for the emergence of regional industrial ecosystems, which strongly relates to the decisions and actions of relevant actors involving industrial organisations of all sizes, governmental and non-governmental organisations, entrepreneurs, universities and research institutes, local champions, managing/coordinating bodies, and the local community.

Finally, we suggest various some further research opportunities. Our conceptual framework can be further tailored and used as an ex-post analytical framework for analysing other empirical cases from the industrial ecology field. Moreover, future studies can seek to analyse socio-technical transitions of industrial production systems through industrial symbiosis. This may require analysis of multi-regime dynamics building also on the multi-level perspective (Geels, 2002; Rip \& Kemp, 1998), which indeed needs to be expanded in the ST field, as other ST scholars have suggested (e.g. Schot \& Kanger, 2018; Raven, 2007).

\section{Acknowledgements}

We would like to thank the four anonymous reviewers and Professor Johan Schot for their insightful and constructive comments. We also acknowledge that this paper was produced as part of the EMJD Programme European Doctorate in Industrial Management (EDIM) funded by the European Commission, Erasmus Mundus Action 1. 


\section{Appendix A - Secondary data inventory}

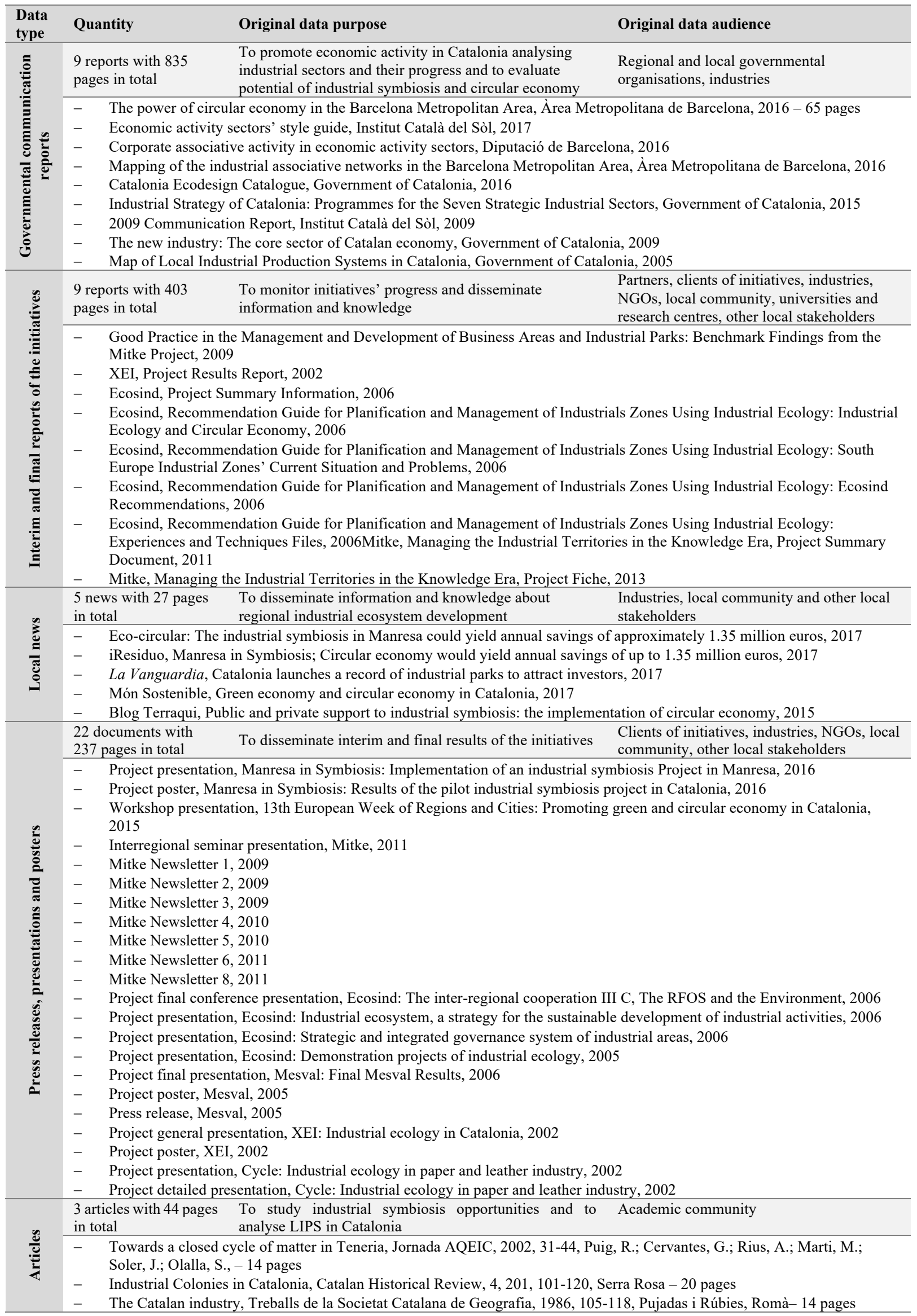




\section{Appendix B - List of interviewees}

\begin{tabular}{|c|c|}
\hline Organisation name & The position of the interviewee \\
\hline \multirow[t]{5}{*}{ Universidad de Guanajuato } & $\begin{array}{l}\text { Professor at Universitat Politècnica de Catalunya from } 1991 \text { till } \\
2008 .\end{array}$ \\
\hline & Co-creator and member of $X E I$ \\
\hline & Expert in CICLE \\
\hline & Coordinator in ECOSIND \\
\hline & Coordinator in $M E S V A L$ \\
\hline \multirow[t]{5}{*}{$\begin{array}{l}\text { Universidad Autonoma de Barcelona, The Institute of } \\
\text { Environmental Science and Technology }\end{array}$} & $\begin{array}{l}\text { Head researcher of the research group on sustainability and } \\
\text { environmental protection. }\end{array}$ \\
\hline & Co-creator and member of $X E I$ \\
\hline & Expert on industrial ecology. Expert in ECOSIND \\
\hline & Expert in $M E S V A L$ \\
\hline & Co-creator and member of Vallès Circular \\
\hline \multirow{2}{*}{$\begin{array}{l}\text { The Government of Catalonia. Secretariat for Housing } \\
\text { and Urban Improvement. Department of Governance, } \\
\text { Public Administrations and Housing }\end{array}$} & Chief Officer of European Programmes. \\
\hline & Director of ECOSIND \\
\hline Incasòl, a public company of the Government & Head of Environmental Department. \\
\hline \multirow{3}{*}{$\begin{array}{l}\text { of Catalonia which is attached to the Department of } \\
\text { Regional Policy responsible for Development of land } \\
\text { for economic activities }\end{array}$} & Project coordinator of $M I T K E$ \\
\hline & Project Development Coordinator \\
\hline & Project Expert in $M I T K E$ \\
\hline \multirow{3}{*}{$\begin{array}{l}\text { Simbiosy, a private key player for industrial symbiosis } \\
\text { in Catalonia linking municipalities, LIPS and other } \\
\text { industrial actors }\end{array}$} & Founder and Director of the company \\
\hline & Founder and Director of the company \\
\hline & $\begin{array}{l}\text { Manager and coordinator of various industrial ecosystem initiatives } \\
\text { in Catalonia including Manresa in Symbiosis }\end{array}$ \\
\hline $\begin{array}{l}\text { Eduard Balcells Architecture, a private architecture } \\
\text { company }\end{array}$ & $\begin{array}{l}\text { Director of the company and principal architect of an industrial } \\
\text { ecosystem initiative, The New Urban Fabric }\end{array}$ \\
\hline $\begin{array}{l}\text { The Vallès Occidental County Council, public body to } \\
\text { coordinate policies and the provision of services to the } \\
\text { public, especially of collaboration and support in } \\
\text { Vallès area of Catalonia }\end{array}$ & $\begin{array}{l}\text { Head of Entrepreneurship and Business Department } \\
\text { Local coordinator of Vallès Circular }\end{array}$ \\
\hline
\end{tabular}

\section{References}

Adamides, E. D. \& Mouzakitis, Y., 2009. Industrial ecosystems as technological niches. Journal of Cleaner Production, 17(2), pp. 172-180.

Argyris, C., 1997. Initiating change that preserves. American Behavioral Scientist, 40(3), pp. 299-310.

Ashton, S. W., 2008. Understanding the organization of industrial ecosystems - A social network approach. Journal of Industrial Ecology, 12(1), pp. 34-51.

Ashton, W. S., 2009. The structure, function, and evolution of a regional industrial ecosystem. Journal of Industrial Ecology, 13(2), pp. 228-246.

Ashton, W. S. \& Bain, A. C., 2012. Assessing the "Short Mental Distance" in Eco-Industrial Networks. Journal of Industrial Ecology, 16(1), pp. 70-82.

Baas, L., 2011. Planning and uncovering industrial symbiosis: Comparing the Rotterdam and Östergötland regions. Business Strategy and the Environment, 20(7), pp. 428-440.

Baas, L. \& Boons, F., 2007. The introduction and dissemination of the industrial symbiosis projects in the Rotterdam Harbour and Industry Complex. International Journal of Environmental Technology and Management, 7(5-6), pp. 551-577. 
Baas, L. W. \& Boons, F. A. A., 2004. An Industrial Ecology Project in Practice: Exploring the Boundaries of Decision-Making Levels in Regional Industrial Systems. Journal of Cleaner Production, 12(8-10), pp. 1073-1085.

Baas, L. W. \& Huisingh, D., 2008. The synergistic role of embeddedness and capabilities in industrial symbiosis: illustration based upon 12 years of experiences in the Rotterdam Harbour and Industry Complex. Progress in Industrial Ecology, An International Journal, 5(6), pp. 399-421.

Behera, S. K. et al., 2012. Evolution of 'designed' industrial symbiosis networks in the Ulsan Eco-industrial Park: 'Research and development into business' as the enabling framework. Journal of Cleaner Production, Volume 29-30, pp. 103-112.

Bergek, A. et al., 2008. Analyzing the functional dynamics of technological innovation systems: a scheme of analysis. Research Policy, Volume 37, pp. 407-429.

Boons, F. et al., 2017. Industrial Symbiosis Dynamics and the Problem of Equivalence: Proposal for a Comparative Framework. Journal of Industrial Ecology, 21(4), pp. 938-952.

Boons, F. \& Spekkink, W., 2012. Levels of Institutional Capacity and Actor Expectations about Industrial Symbiosis: Evidence from the Dutch Stimulation Program 1999-2004. Journal of Industrial Ecology, 16(1), pp. 61-69.

Boons, F., Spekkink, W. \& Mouzakitis, Y., 2011. The dynamics of industrial symbiosis: a proposal for a conceptual framework based upon a comprehensive literature review. Journal of Cleaner Production, Volume 19, pp. 905-911.

Boon, W. P. C., Moors, E. H. M. \& Meijer, A. J., 2014. Exploring dynamics and strategies of niche protection. Research Policy, 43(4), pp. 792-803.

Caniëls, M. C. \& Romijn, H. A., 2008. Strategic niche management: towards a policy tool for sustainable development. Technology Analysis and Strategic Management, 20(2), pp. 245-266.

Chertow, M. R., 2000. Industrial Symbiosis: Literature and Taxonomy. Annual Review of Energy and the Environment, Volume 25, pp. 313-337.

Chertow, M. R., Ashton, W. S. \& Espinosa, J. C., 2008. Industrial Symbiosis in Puerto Rico: Environmentally Related Agglomeration Economies. Regional Studies, 42(10), pp. 1299-1312.

Chopra, S. S. \& Khanna, V., 2014. Understanding resilience in industrial symbiosis networks: Insights from network analysis. Journal of Environmental Management, Volume 141, pp. 86-94.

Coenen, L., Raven, R. \& Verbong, G., 2010. Local niche experimentation in energy transitions: A theoretical and empirical exploration of proximity advantages and disadvantages. Technology in Society, Volume 32, pp. 295-302.

Côté, R. P. \& Liu, C., 2016. Strategies for reducing greenhouse gas emissions at an industrial park level: A case study of Debert Air Industrial Park, Nova Scotia. Journal of Cleaner Production, Volume 114, pp. 352-361.

Creswell, J., 2009. Research Design - Qualitative, Quantitative and Mixed Methods Approaches. 3rd ed. Thousand Oaks, CA: Sage Publications. 
Creswell, J. \& Clark, V. L. P., 2007. Designing and conducting mixed methods research. s.1.:Wiley Online Library.

Daddi, T. et al., 2016. Regional policies and eco-industrial development: The voluntary environmental certification scheme of the eco-industrial parks in Tuscany (Italy). Journal of Cleaner Production, Volume 114, pp. $62-70$.

Denzin, N. \& Lincoln, Y., 2005. Introduction: The discipline and practice of qualitative research. In: Handbook of Qualitative Research. 2nd Edition ed. Thousand Oaks: Sage.

Deutz, P. \& Gibbs, D., 2008. Industrial Ecology and Regional Development: Eco-Industrial Development as Cluster Policy. Regional Studies, 42(10), pp. 1313-1328.

Deutz, P. \& Lyons, D. I., 2008. Editorial: Industrial symbiosis - an enironmental perspective on regional development. Regional Studies, 42(10), pp. 1295-1298.

Domenech, J. \& Ramos, J., 2016. Technology Transfer and the Early Development of the Cotton Textile Industry in Nineteenth Century Spain. In: T. Hashino \& K. Otsuka, eds. Industrial Districts in History and the Developing World. Singapore: Springer Nature, pp. 25-42.

Domenech, T. \& Davies, M., 2011. The role of Embeddedness in Industrial Symbiosis Networks: Phases in the Evolution of Industrial Symbiosis Networks. Business Strategy and the Environment, Volume 20, pp. 281-296.

Dubois, A. \& Gadde, L.-E., 2002. Systematic combining: an abductive approach to case research. Journal of Business Research, Volume 55, p. 553 - 560.

Ehrenfeld, J., 2003. Putting a spotlight on metaphors and analogies in industrial ecology. Journal of Industrial Ecology, Volume 7, p. 1-4.

Eisenhardt, K., 1989. Building theory from case study research. The Academy of Management Review, 14(4), pp. 532-550.

Eisenhardt, K. M. \& Graebner, M. E., 2007. Theory Building from Cases : Opportunities and Challenges. The Academy of Management Journal, 50(1), pp. 25-32.

Farla, J., Markard, J., Raven, R. \& Coenen, L., 2012. Sustainability transitions in the making: A closer look at actors, strategies and resources. Technological Forecasting \& Social Change, Volume 79, p. 991998.

Fernández, I. \& Ruiz, M. C., 2009. Descriptive model and evaluation system to locate sustainable industrial areas. Journal of Cleaner Production, Volume 17, pp. 87-100.

Flyvbjerg, B., 2006. Five Misunderstandings About Case-Study Research. Qualitative Inquiry, 12(2), pp. 219-245.

Frosch, R. A. \& Gallapoulus, N. E., 1989. Strategies for manufacturing. Scientific American, Volume 261, p. 94-102.

Geels, F., 2004. From Sectoral Systems of Innovation to Socio-Technical Systems. Insights about dynamics and change from sociobiology and instituional theory. Research Policy, Volume 33, pp. 897920. 
Geels, F., 2010. Ontologies, socio-technical transitions (to sustainability), and the multi-level perspective. Research Policy, Volume 39, p. 495-510.

Geels, F. W., 2002. Technological transitions as evolutionary reconfiguration processes: A multi-level perspective and a case study. Research Policy, Volume 31, pp. 1257-1274.

Geels, F. W. \& Raven, R., 2006. Non-linearity and expectations in niche-development trajectories: Ups and downs in Dutch biogas development (1973-2003). Technology Analysis and Strategic Management, 18(3-4), pp. 375-392.

Geng, Y., Zhang, P., Côté, R. P. \& Qi, Y., 2008. Evaluating the applicability of the Chinese eco-industrial park standard in two industrial zones. International Journal of Sustainable Development and World Ecology, 15(6), pp. 543-552.

Ghali, M. R., Frayret, J. M. \& Robert, J. M., 2014. Green social networking: Concept and potential applications to initiate industrial synergies. Journal of Cleaner Production, Volume 115, pp. 23-35.

Gibbs, D., 2008. Industrial Symbiosis and Eco-Industrial Development: An Introduction. Geography Compass, Volume 2, pp. 1138-1154.

Gibbs, D., 2009. Eco-industrial Parks and Industrial Ecology: Strategic Niche or Mainstream Development. In: The Social Embeddedness of Industrial Ecology. Cheltenham: Edward Elgar, pp. 73102.

Gioia, D. A., Price, K. N., Hamilton, A. L. \& Thomas, J. B., 2010. Forging an Identity: An Insider-outsider Study of Processes Involved in the Formation of Organizational Identity. Administrative Science Quarterly, Volume 55, pp. 1-46.

Giurco, D., Bossilkov, A., Patterson, J. \& Kazaglis, A., 2011. Developing industrial water reuse synergies in Port Melbourne: Cost effectiveness, barriers and opportunities. Journal of Cleaner Production, Volume 19, pp. 867-876.

Grant, G. B., Seager, T. P., Massard, G. \& Nies, L., 2010. Information and Communication Technology for Industrial Symbiosis. Journal of Industrial Ecology, 14(5), pp. 740-753.

Hassan, E., 2005. Recall Bias can be a Threat to Retrospective and Prospective Research Designs. The Internet Journal of Epidemiology, 3(2), pp. 1-7.

Heckathorn, D., 2002. Respondent-Driven Sampling II: Deriving Valid Estimates from Chain-Referrel Samples of Hidden Populations.. Social Problems, Volume 49, p. 11-34.

Heeres, R. R., Vermeulen, W. J. V. \& De Walle, F. B., 2004. Eco-industrial park initiatives in the USA and the Netherlands: First Lessons. Journal of Cleaner Production, Volume 12, pp. 985-995.

Hekkert, M. P. \& Negro, S. O., 2009. Functions of innovation systems as a framework to understand sustainable technological change: Empirical evidence for earlier claims. Technological Forecasting \& Social Change, Volume 76, p. 584-594.

Hernández, J. M., Fontrodona, J. \& Pezzi, A., 2005. Map of Local Industrial Production Systems in Catalonia, Barcelona: Ministry of Employment and Industry of the Autonomous Government-Department of Industry. 
Hewes, A. K. \& Lyons, D. I., 2008. The Humanistic Side of Eco-Industrial Parks: Champions and the Role of Trust. Regional Studies, 42(10), pp. 1329-1342.

Hox, J. J. \& Boeije, H. R., 2005. Data Collection, Primary vs. Secondary. Encyclopedia of Social Measurement, Volume 1, pp. 593-599.

Incasòl, T. C. L. I., 2007. Sectors of Economic Activity-Style Book, Barcelona: Incasòl.

Kemp, R., Schot, J. \& Hoogma, R., 1998. Regime shifts to sustainability through processes of niche formation: the approach of strategic niche management. Technology Analysis and Strategic Management, Volume 10, p. 175-195.

Korhonen, J., Wihersaari, M. \& Savolainen, I., 2001. Industrial ecosystem in the Finnish forest industry: Using the material and energy flow model of a forest ecosystem in a forest industry system. Ecological Economics, 39(1), pp. 145-161.

Lambert, A. J. D. \& Boons, F. A., 2002. Eco-industrial parks: Stimulating sustainable development in mixed industrial parks. Technovation, Volume 22, pp. 471-484.

Lincoln, Y. S. \& Guba, E. G., 1985. Naturalistic Inquiry. Beverly Hills, CA: SAGE.

Liu, Z. et al., 2017. Comprehensive development of industrial symbiosis for the response of greenhouse gases emission mitigation: Challenges and opportunities in China. Energy Policy, Volume 102, pp. 8895.

Lombardi, D. R. \& Laybourn, P., 2012. Redefining Industrial Symbiosis: Crossing Academic-Practitioner Boundaries. Journal of Industrial Ecology, 16(1), pp. 28-37.

Lombardi, D. R., Lyons, D., Shi, H. \& Agarwal, A., 2012. Industrial symbiosis: Testing the Boundaries and Advancing Knowledge. Journal of Industrial Ecology, 16(1), pp. 2-7.

Lowe, E. A. \& Evans, L. K., 1995. Industrial ecology and industrial ecosystems. Journal of Cleaner Production, Volume 3, pp. 47-53.

Machiba, T., 2010. Eco-innovation for enabling resource efficiency and green growth: development of an analytical framework and preliminary analysis of industry and policy practices. International Economics and Economic Policy, Volume 7, p. 357-370.

MacLachlan, I., 2013. Kwinana Industrial Area: agglomeration economies and industrial symbiosis on Western Australia's Cockburn Sound. Australian Geographer, 44(4), pp. 383-400.

Markard, J., Raven, R. \& Truffer, B., 2012. Sustainability transitions: An emerging field of research and its prospects. Research policy, Volume 41, pp. 955-967.

McManus, P. \& Gibbs, D., 2008. Industrial ecosystems? The use of tropes in the literature of industrial ecology and eco-industrial parks. Progress in Human Geography, 32(4), pp. 525-540.

Meyer, S. \& Ward, P., 2014. 'How to' Use Social Theory Within and Throughout Qualitative Research in Healthcare Contexts. Sociology Compass, 8(5), pp. 525-539.

Miles, M. B., 1979. Qualitative Data as an Attractive Nuisance: The Problem of Analysis. Administrative Science Quarterly, 24(4), pp. 590-601. 
Mirata, M. \& Emtairah, T., 2005. Industrial symbiosis networks and the contribution to environmental innovation: The case of the Landskrona industrial symbiosis programme. Journal of Cleaner Production, Volume 13, pp. 993-1002.

Mulrow, J. S., Derrible, S., Ashton, W. S. \& Chopra, S. S., 2017. Industrial Symbiosis at the Facility Scale. Journal of Industrial Ecology, 21(3), pp. 559-571.

OECD, 2009. Sustainable Manufacturing and Eco-Innovation: Framework, Practices and Measurement, 2009: OECD: Organisation for Economic Co-operation and Development.

Qu, Y., Liu, Y., Nayak, R. R. \& Li, M., 2015. Sustainable development of eco-industrial parks in China: effects of managers' environmental awareness on the relationships between practice and performance. Journal of Cleaner Production, Volume 87, pp. 328-338.

Raven, R., 2005. Strategic Niche Management for Biomass Strategic Niche Management for Biomass: A comparative study on the experimental introduction of bioenergy technologies in the Netherlands and Denmark, s.1.: Eindhoven University Press.

Raven, R., 2006. Towards alternative trajectories? Reconfigurations in the Dutch elecetricity regime. Research Policy, Volume 35, pp. 581-595.

Raven, R., 2007. Co-evolution of waste and electricity regimes: Multi-regime dynamics in the Netherlands (1969-2003). Energy Policy, Volume 35, pp. 2197-2208.

Raven, R. \& Geels, F., 2010. Socio-cognitive evolution in niche development: Comparative analysis of biogas development in Denmark and the Netherlands (1973-2004). Technovation, Volume 30, pp. 87-99.

Rip, A. \& Kemp, R., 1998. Technological Change. In: Human Choice and Climate Change - Resources and Technology. Columbus, OH: Battelle Press, pp. 327-399.

Ristola, P. \& Mirata, M., 2007. Industrial symbiosis for more sustainable, localised production. Progress in Industrial Ecology - An International Journal, Volume 4, p. 184-204.

Roberts, B., 2004. The application of industrial ecology principles and planning guidelines for the development of eco-industrial parks: an Australian case stud. Journal of Cleaner Production, Volume 12, pp. 997-1010.

Rosano, M. \& Schianetz, K., 2014. Measuring sustainability performance in industrial parks: A case study of the Kwinana industrial area. International Journal of Sustainable Development, 17(3), pp. 261-280.

Rotmans, J. \& Loorbach, D., 2009. Complexity and Transition Management. Journal of Industrial Ecology, 13(2), pp. 184-196.

Schot, J. \& Geels, F. W., 2008. Strategic niche management and sustainable innovation journeys: theory, findings, research agenda, and policy. Technology Analysis \& Strategic Management, 20(5), pp. 537-554.

Schot, J. \& Kanger, L., 2018. Deep transitions: Emergence, acceleration, stabilization and directionality. Research Policy, 47(6), pp. 1045-1059.

Schultze, U. \& Avital, M., 2011. Designing interviews to generate rich data for information systems research. Information and Organization, Volume 21, pp. 1-16. 
Shi, H., Chertow, M. \& Song, Y., 2010. Developing country experience with eco-industrial parks: a case study of the Tianjin Economic-Technological Development Area in China. Journal of Cleaner Production, Volume 18, pp. 191-199.

Smith, A., 2006. Green niches in sustainable development: the case of organic food in the United Kingdom. Environment and Planning C, Volume 24, pp. 439-458.

Smith, A. \& Raven, R., 2012. What is protective space? Reconsidering niches in transitions to sustainability. Research Policy, Volume 41, p. 1025-1036.

Spekkink, W., 2013. Institutional capacity building for industrial symbiosis in the Canal Zone of Zeeland in the Netherlands: A process analysis. Journal of Cleaner Production, Volume 52, pp. 342-355.

Sterr, T. \& Ott, T., 2004. The industrial region as a promising unit for eco-industrial development Reflections, practical experience and establishment of innovative instruments to support industrial ecology. Journal of Cleaner Production, Volume 12, pp. 947-965.

Sushandoyo, D. \& Magnusson, T., 2014. Strategic niche management from a business perspective: Taking cleaner vehicle technologies from prototype to series production. Journal of Cleaner Production, Volume 74, pp. 17-26.

Taddeo, R., Simboli, A., Ioppolo, G. \& Morgante, A., 2017. Industrial symbiosis, networking and innovation: The potential role of innovation poles. Sustainability, 9(169), pp. 1-17.

Tessitore, S., Daddi, T. \& Iraldo, F., 2015. Eco-Industrial Parks Development and Integrated Management Challenges: Findings from Italy. Sustainability, Volume 7, pp. 10036-10051.

Truffer, B. \& Coenen, L., 2012. Environmental Innovation and Sustainability Transitions in Regional Studies. Regional Studies, 46(1), pp. 1-21.

UNIDO, 2014. First Forum: ISID - Inclusive and Sustainable Industrial Development, Vienna: UNIDO: United Nations Industrial Development Organization.

UNIDO, U. N. I. D. O., 2012. Europe and Central Asia Regional Conference on Industrial Parks as a Tool to Foster Local Industrial Development, Vienna: UNIDO.

Valentine, S. V., 2016. Kalundborg Symbiosis: fostering progressive innovation in environmental networks. Journal of Cleaner Production, Volume 118, pp. 65-77.

Van der Laak, W. W. M., Raven, R. P. J. M. \& Verbong, G. P. J., 2007. Strategic niche management for biofuels: Analysing past experiments for developing new biofuel policies. Energy Policy, Volume 35, pp. 3213-3225.

Van Eijck, J. \& Romijn, H., 2008. Prospects for Jatropha biofuels in Tanzania: An analysis with Strategic Niche Management. Energy Policy, 36(1), pp. 311-325.

Veleva, V., Lowitt, P., Angus, N. \& Neely, D., 2016. Benchmarking eco-idustrial park development: the case of Deves. Benchmarking: An International Journal, 23(5), pp. 1147-1170.

Veleva, V. et al., 2015. Understanding and addressing business needs and sustainability challenges: lessons from Devens eco-industrial park. Journal of Cleaner Production, Volume 87, pp. 375-384. 
Verbong, G., Christiaens, W., Raven, R. \& Balkema, A., 2010. Strategic Niche Management in an unstable regime: Biomass gasification in India. Environmental Science and Policy, 13(4), pp. 272-281.

Verguts, V. et al., 2016. Industrial symbiosis as sustainable development strategy: adding a change perspective. International Journal of Sustainable Development, 19(1), pp. 15-35.

Walrave, B. \& Raven, R., 2016. Modelling the dynamics of technological innovation systems. Research Policy, Volume 45, p. 1833-1844.

Weber, M., Hoogma, R., Lane, B. \& Schot, J., 1999. Experimenting with Sustainable Transport Innovations. A workbook for Strategic Niche Management, Seville/Enschede: Twente University.

Yin, R. K., 2014. Case Study Research: Design and Methods. 5th Edition ed. California: SAGE.

Yu, C., De Jong, M. \& Dijkema, G. P. J., 2014. Process analysis of eco-industrial park development - The case of Tianjin, China. Journal of Cleaner Production, Volume 64, pp. 464-477.

Yu, F., Han, F. \& Cui, Z., 2015. Evolution of industrial symbiosis in an eco-industrial park in China. Journal of Cleaner Production, Volume 87, pp. 339-347.

Zhu, J. \& Ruth, M., 2014. The development of regional collaboration for resource efficiency: A network perspective on industrial symbiosis. Computers, Environment and Urban Systems, Volume 44, pp. 37-46. 